\title{
IS EMPLOYMENT GLOBALIZING?
}

\author{
Liming Chen, Jesus Felipe, Andrew J.Y. Kam, and Aashish Mehta
}

NO. 556

September 2018
ADB ECONOMICS WORKING PAPER SERIES 
ADB Economics Working Paper Series

\section{Is Employment Globalizing?}

Liming Chen, Jesus Felipe, Andrew J.Y. Kam, and Aashish Mehta

No. 556 | September 2018
Liming Chen (limingchen_cn@hotmail.com) is a Postdoctoral Fellow at the Institute of International Economics of Nankai University. Jesus Felipe (jfelipe@adb.org) is an Advisor at the Economic Research and Regional Cooperation Department of the Asian Development Bank. Andrew J.Y. Kam (andrew@ukm.edu.my) is an Associate Professor and Senior Research Fellow at the Institute of Malaysian and International Studies of the National University of Malaysia. Aashish Mehta (mehta@global.ucsb.edu) is an Associate Professor at the Department of Global Studies of the University of California Santa Barbara.

The authors would like to thank Bart Verspagen, Jan Nederveen Pieterse, James Galbraith, and participants in UCSB's Global Studies lunch seminar for excellent discussions and feedback. 
(C) 2018 Asian Development Bank

6 ADB Avenue, Mandaluyong City, 1550 Metro Manila, Philippines

Tel +632632 4444; Fax +6326362444

www.adb.org

Some rights reserved. Published in 2018.

ISSN 2313-6537 (print), 2313-6545 (electronic)

Publication Stock No. WPS189526-2

DOI: http://dx.doi.org/10.22617/WPS189526-2

The views expressed in this publication are those of the authors and do not necessarily reflect the views and policies of the Asian Development Bank (ADB) or its Board of Governors or the governments they represent.

ADB does not guarantee the accuracy of the data included in this publication and accepts no responsibility for any consequence of their use. The mention of specific companies or products of manufacturers does not imply that they are endorsed or recommended by ADB in preference to others of a similar nature that are not mentioned.

By making any designation of or reference to a particular territory or geographic area, or by using the term "country" in this document, $A D B$ does not intend to make any judgments as to the legal or other status of any territory or area.

This work is available under the Creative Commons Attribution 3.0 IGO license (CC BY 3.0 IGO)

https://creativecommons.org/licenses/by/3.o/igo/. By using the content of this publication, you agree to be bound by the terms of this license. For attribution, translations, adaptations, and permissions, please read the provisions and terms of use at https://www.adb.org/terms-use\#openaccess.

This CC license does not apply to non-ADB copyright materials in this publication. If the material is attributed to another source, please contact the copyright owner or publisher of that source for permission to reproduce it. $\mathrm{ADB}$ cannot be held liable for any claims that arise as a result of your use of the material.

Please contact pubsmarketing@adb.org if you have questions or comments with respect to content, or if you wish to obtain copyright permission for your intended use that does not fall within these terms, or for permission to use the ADB logo.

Notes:

In this publication, "\$” refers to United States dollars.

ADB recognizes "China" as the People's Republic of China.

Corrigenda to ADB publications may be found at http://www.adb.org/publications/corrigenda. 


\section{CONTENTS}

TABLES AND FIGURES

ABSTRACT

I. INTRODUCTION 1

II. DEFINITIONS, DISTINCTIONS, AND IMPORTANCE 4

A. Definitions and Motivations 4

B. Distinctions and Relationships 5

C. $\quad$ Relevance of Particular Measures to Particular Policy Discussions 6

III. RESULTS 8

A. Export-Induced Labor Demand 8

B. Tradable Employment $\quad 12$

C. Trade-Linked Employment 22

D. A Composite View for Some Large Economies 25

$\begin{array}{lll}\text { IV. } & \text { DISCUSSION AND IMPLICATIONS FOR POLICY } & 28\end{array}$

$\begin{array}{ll}\text { APPENDIXES } & 30\end{array}$

$\begin{array}{ll}\text { REFERENCES } & 35\end{array}$ 


\section{TABLES AND FIGURES}

\section{TABLES}

1 Distinguishing Our Three Notions of Internationally Interconnected Labor Markets

2 The Correlates of Export-Induced Labor Demand

3 Lower and Upper Bound Estimates of the Share of Employment that Is Intrinsically Tradable

$4 \quad$ Intrinsically Trade-Linked Employments, Upper and Lower Bounds

5 Tradable Employment, Trade-Linked Employment, and Export-Induced Labor Demand for a Common Set of Economics and Years

A4 Assumed Level of Intrinsic Tradability of WIOD and 1-Digit Level ISIC Industries

\section{FIGURES}

1 The Percentage of Labor Demand that Is Export Induced

5 No Across-the-Board Evidence that Trade-Linked Employment Increased

6 No Across-the-Board Evidence that Trade-Linked Employment (Excluding Agriculture) Increased 


\begin{abstract}
We investigate the claim that national labor markets have become more globally interconnected in recent decades. We do so by deriving estimates over time of three different notions of interconnection: (i) the share of labor demand that is export induced (i.e., all labor demand created by foreign entities buying products exported by the home country) - we provide estimates for 40 countries; (ii) the share of workers employed in sectors producing tradable goods or services-68 countries; and (iii) the ratio of the number of jobs that are either located in a tradable sector, or that are involved in producing services that are required by these tradable sectors, to all jobs in the economy, which we call the trade-linked employment share-40 countries. Our estimates lead to the conclusion that the evidence of a large increase in the interconnections between national labor markets is far weaker than commonly asserted: levels of interconnectivity, and the direction of changes over time, vary across notions of interconnection and countries. The main reasons for this are labordisplacing productivity growth in tradable sectors of each economy and the diminishing fraction of national labor forces hired into manufacturing jobs worldwide. We also discuss the implications of our results for different policy debates that each of the three measures is associated with: international coordination of macroeconomic policies (export-induced labor demand), currency devaluations (share of workers producing tradables), and education and labor protection (trade-linked share).
\end{abstract}

Keywords: employment, export induced, globalization, tradable goods, trade-linked employment

JEL codes: F60, F63, F66, F68 
"The kids in L.A. are not competing for jobs with kids in Compton; they're competing with kids in China. They're not competing for jobs with kids in Inglewood, it's India. This is very much a global society."

- John Deasy, Superintendent, Los Angeles Unified School District ${ }^{1}$

"Clearly, it is now possible for more people than ever to collaborate and compete in real time with more other people on more different kinds of work from more different corners of the planet and on a more equal footing than at any previous time in the history of the world.."

- Thomas Friedman (2005), The World is Flat, p. 8

"...the ones who are not capable of creating jobs and do not have the opportunities, they must be in a position to face their counterparts in any corner of the world while keeping their heads high by virtue of their hard work and their dexterity of hands and win the hearts of people around the world through their skills....having taken a resolve to enhance the skill development at a highly rapid pace, I want to accomplish this."

- Narendra Modi (2014), Independence Day Speech

\section{INTRODUCTION}

Politicians, policy makers and journalists frequently allude to the idea that labor markets have become more internationally interconnected. Our three epigraphs provide a flavor. The presumed globalization of work, it is argued (e.g., Freeman 2007), is driven by changes in technology (e.g., supply chain management software, electronic communications, containerization) and to policies (e.g., trade liberalization, education expansion in developing countries) that have made it possible to wrap industrial supply chains through multiple countries and to trade new services over the internet. This enhanced scope for international trade and collaboration, it is often claimed, has implications for employment-related policies. For example, governments and intergovernmental agencies routinely emphasize the growing need to change human resource policies in order to withstand or overcome competition. Education reforms to promote skill development and relaxation of proworker labor regulations are common targets (e.g., Beach 2013, Chenoy 2013, World Economic Forum 2015). Somewhat less publicly, export industry lobby groups emphasize the need to keep currencies cheap in the face of growing international competition, with the objective of exporting and preserving jobs. Policy makers, including the International Monetary Fund, now emphasize the importance of coordinating countercyclical policies internationally (e.g., Blanchard 2008, Lagarde 2016). The idea of an increasingly global labor market therefore has considerable hold on the public imagination, and accepting it has consequences for policy.

In this paper, we argue that the idea of a more internationally interconnected labor market is not adequately understood, conceptual or empirically. Our efforts help rectify this situation. The conceptual problem arises because different policy debates are actually invoking different notions of international interconnectedness. We address three such notions in this paper, each of which, we suggest, is relevant to a different policy discussion. The empirical problem is that, for a variety of

\footnotetext{
Interview on The Tavis Smiley Show, 25 March 2013. http://www.pbs.org/wnet/tavissmiley/interviews/lausd-superintendent-
} dr-john-deasy/. 
reasons, these notions of interconnectedness have not been measured on a consistent basis over time and across countries. ${ }^{2}$

The first notion of interconnectedness is often discussed by macroeconomists, who ask how much of the demand for a country's labor arises to meet final demand for its goods and services in other countries. Higher levels of export-induced labor demand are taken to increase the importance of international coordination to avoid free riding by countries on each other's stimulus policies. Thus, this is the notion invoked by policy makers discussing such coordinated interventions (Lagarde 2016, Blanchard 2008). Second, the international trade and finance literature refers to the fraction of the workforce employed in those sectors of the economy producing tradable goods and services (i.e., products/services that could be bought from or sold in other countries). Among other things, knowing this tradable employment share sheds light on the welfare implications of currency undervaluation, a phenomenon whose costs are felt by consumers, but whose benefits tend to accrue to producers of tradables (Obstfeld, Rogoff, and Wren-Lewis 1996; Frieden 2014).

The third notion, unlike the first two, does not appear to be well established in the economics literature. Rather, it is implicit in claims that adjustments to the policies and institutions regulating human resources (i.e., education and labor relations) are required to permit economies to weather growing international competition. We will argue that to assess whether such claims are correct or not, one must measure the number of jobs that are either located in a tradable sector, or that are involved in producing goods or services that are required by these tradable sectors. We call the ratio of these jobs to all jobs in the economy, the trade-linked employment share. ${ }^{3}$

Trends in tradable employment and export-induced labor demand have been studied in advanced economies (Jensen 2011, Jensen et al. 2005, Blinder and Krueger 2013, Blinder 2009, Ebenstein et al. 2014). ${ }^{4}$ However, other than the occasional single-country study, we know of no attempts to measure them in low- and middle-income economies, and have not seen any studies that estimate trade-linked employment. Notwithstanding its acknowledged importance for policy, the

2 Other possible notions of labor markets interconnection have been considered in the literature, but one paper cannot cover them all. We do not, for example, consider international migration, which has grown relative to the populations of receiving, but not sending countries (Czaika and Haas 2014).

3 Previous studies attempt to (crudely) estimate trade-linked employment at the national level, or, as they describe it, the "amount of labor which is engaged in producing goods which are traded internationally" (Harrigan and Balaban 1999, pp. 15-16) by multiplying the labor force by the ratio of gross trade (exports plus imports) to gross domestic product (GDP) (Jaumotte and Tytell [2008] do likewise at the global level, using the exports in place of the gross trade to prevent double-counting). These are early attempts to estimate trade-linked employment. More loosely, Freeman (2007) defines the "global labor force" to include all workers in countries that are broadly open to trade, regardless of whether those workers are involved in producing tradable products. He estimates that this figure doubled due to the economic opening of India, the People's Republic of China (PRC), and the countries of the former Soviet bloc.

4 Export-induced employment has been estimated for several countries, but typically to compare the employment effects of exports to those of domestic sales. A typical finding is that while a unit of export demand generates less employment than a unit of domestic demand-because exports use more imported intermediate inputs-exports could generate lots of labor demand because export demand is quite elastic (e.g., Athukorala and Santosa 1997; Los, Timmer, and de Vries 2012; Chen et al. 2012; Feenstra and Hong 2010). We have found no papers that have attempted to compare the fraction of a country's labor demand that is export linked over time. Blinder (2009) and Blinder and Krueger (2013) attempt to estimate the offshorability (i.e., the possibility that the tasks performed by the occupation be undertaken abroad) of United States (US) occupations, a notion obviously related to tradability. Blinder (2009) ranks 291 US occupations for 2004 by offshorability. He concludes that the outer limit of potential offshorability ranged from $22 \%$ to $29 \%$ of the US jobs, and that the more offshorable occupations are not low-end jobs. Blinder and Krueger (2013) also conclude that about $25 \%$ of all US jobs are offshorable; that most of these jobs are performed by well-educated workers; that differences in offshorability by race, sex, age, and geographic region are minor; and that offshorability does not have systematic effects on wages or the probability of layoff. 
question of just how "global" labor markets around the world are actually becoming, has therefore received little empirical attention from academics.

We suspect that this lack of attention stems from the formidable data challenges involved. Internationally and temporally comparable data on employment by industry are unavailable for many countries. The same is true of the input-output tables necessary to study how employment is linked to trade through sales of intermediate goods and services. And, crucially, it is generally unknown how much of an industry's output was in fact free to flow across international borders at any point in time.

Nevertheless, because partial answers are better than no answers at all, we attempt to characterize the size and/or trajectory over time of these interconnections for as many countries as possible. Our methodological contribution is to show how, and to what extent, this can be done, despite the data challenges. These challenges ensure that our conclusions regarding how interconnected labor markets are becoming in each dimension will be subject to assumptions, and often based on bounds analyses, rather than point estimates. To ensure that our results are robust, we draw on three different sources suitable for studying employment across countries and time. To keep our claims conservative, we attempt to test every assumption we invoke, or reflect on the work of others who have.

One might question, at the outset, whether these efforts are necessary. After all, previous studies do provide strong evidence that workers within particular industries increasingly have competitors, collaborators, and customers abroad (Deyo 2016; Dedrick, Kraemer, and Linden 2010; Timmer et al. 2014; Gereffi and Frederick 2010). We do not dispute this evidence. Yet, theory cautions against characterizing national trends based on what happens within particular industries. The international division of labor, so clear in the industries in question, can dramatically increase the level of output per worker of such industries (Smith 1776), so that internationalizing industries might therefore shed workers. The share of workers employed in industries that either produce tradables or are trade linked could fall, as might the share of labor that is employed to meet export demand. In the deindustrializing United States (US), for example, 98\% of net employment creation between 1990 and 2008 occurred in nontradable services (Spence and Hlatshwayo 2011). As early deindustrialization in employment becomes a worldwide phenomenon (Rodrik 2016; Felipe, Mehta, and Rhee 2018), and agricultural employment shares continue to decline in most countries, this tendency to create jobs in less trade-dependent sectors may well be spreading. The question is therefore an empirical one.

Our results will underscore the importance of looking at multiple definitions of labor interconnection, and of not generalizing across countries. Holding the definition constant, both the level of interconnectedness and-perhaps more surprisingly-its trend, vary across countries. Similarly, both levels and trends vary across definitions within the same country. The following general results can be stated to orient the reader:

(i) The share of labor demand that is export induced has grown rapidly in some (mostly European) countries, grown slowly in more, and shrunk in a few (mostly advanced nonEuropean) economies. This happened because, even as most sectors of most economies became more export oriented, rapid increases in output per worker in the most exportoriented sectors reduced the number of workers they hired. This pushed workers into sectors of the economy more reliant on domestic demand. The balance of these two countervailing forces determined the specific outcome in each country. 
(ii) Second, the share of workers producing intrinsically tradable products (goods and services that would be tradable if trade restrictions were lifted) almost certainly trended downward with economic development over time: workers moved out of agriculture (an intrinsically tradable sector) and into services (a historically nontradable sector), faster than technological change rendered those services jobs tradable. ${ }^{5}$ It is not possible to say whether the lifting of trade restrictions permitted the share of workers in de facto tradable sectors (those that are actually tradable given trade rules at the time) to rise despite this downward trend. However, even with technological change, long term trends suggest that we are headed for a world in which no more than $15 \%-40 \%$ of most country's workers will be hired to produce tradable goods or services.

(iii) Meanwhile, the general decline in employment in intrinsically tradable sectors has been offset by increases in these sectors' backward linkages into nontradable sectors, so that for 30 of the 40 countries for which we can make these calculations, it is impossible to discern unambiguous increases or decreases in trade-linked employment. For 10 countries, trade-linked employment appears to have declined unambiguously.

It follows that work has globalized in some dimensions and countries, but deglobalized in others, depending on what aspect of a globalized labor market one is interested in. The implication is that platitudes about globalization of labor markets are seriously misleading. Policy makers need to adopt a both case- and policy-specific approach to thinking about how globalization is and is not changing the economic landscape and the menu of policy options they confront.

The remainder of this paper is structured as follows. Section II defines and distinguishes our three measures of interconnection. Section III provides our methods and results separately for each measure, followed by an attempt to characterize countries by their experience with respect to the globalization of employment. Section IV recaps the limitations of our work, points to directions for future research, and discusses policy implications. Appendix 1 provides details on the estimation of export-induced and trade-linked labor demand. Appendix 2 explains how we cleaned the International Labour Organization (ILO) dataset. Appendix 3 summarizes our findings on intrinsically tradable employment using an alternative dataset. Finally, Appendix 4 shows our upper and lower estimates of intrinsically tradable employment for each sector.

\section{DEFINITIONS, DISTINCTIONS, AND IMPORTANCE}

Table 1 defines, distinguishes, and motivates our measures of interconnectivity.

\section{A. Definitions and Motivations}

Our first measure of interconnectedness is the fraction of the labor demanded from a country's workforce that is demanded to meet foreign demand for final goods and services (export-induced labor demand share, EILD). It captures all labor demand created by foreign entities buying products exported by the home country. This includes labor demanded from workers in nontradable sectors, such as the labor demand from a truck driver who transports a tennis racket from a factory to a port for

5 The manufacturing sector no longer plays much of a role, as the spread of manufacturing capabilities to less advanced but more populous economies limits the sector's share of employment (Felipe and Mehta 2016; Felipe, Mehta, and Rhee 2018; ADB 2018). 
export, as well as labor demanded from the financiers, salespeople, and lawyers who made the export deal possible. It also includes the labor demanded from the factory workers producing the tennis rackets, and from all those involved in producing the intermediate goods that went into it. EILD is imputed from the sales of final and intermediate goods recorded in input-output tables.

Second, one might consider the share of workers employed in sectors of the economy producing tradable products (goods or services). We shall refer to this figure as the tradable employment share. This is a concept utilized widely in trade theory, where the key distinction between tradable and nontradable products is that, given transport costs, tradable products need not be produced in proximity to the buyer, but may be delivered cheaply and effectively from a distance. As a result, in most basic trade models, the prices of tradable products relative to each other are set in world markets. In contrast, the relative prices of nontradables are determined by relative production costs in local markets. Conceptually, a sector producing a tradable product is a tradable sector, and the workers employed in it contribute to the country's tradable employment share. Tradable sectors include those that compete in overseas markets, and those that are import competing. Tradable employment shares are usually estimated from labor force surveys, by counting the workers whose primary jobs are in industries deemed to be tradable.

Our third measure is the fraction of workers who are trade linked. We define a worker to be trade linked if their contribution to production, per dollar spent on their wages has bearing on the country's trade competitiveness. As this measure is not a mainstay in the literature, we make our example more specific, and consider a hypothetical economy that produces only three products/services: shoes, which it produces for domestic consumption and which face competition from imports; tennis rackets, some of which it exports; and trucking services, which are sold to domestic consumers (to move house) as well as to shoe and racket factories. Clearly (holding exchange rates and other factor prices constant), the country's competitiveness in shoes depends on the productivity and pay of workers in shoe factories, and on that of those truckers who transport raw inputs to shoe factories and shoes to market. If their pay increases, or their productivity falls, then, other things equal, shoe imports will rise and employment related to shoe production will decline. Similarly, the country's competitiveness in tennis rackets depend upon the productivity and pay of workers in racket factories and of those truckers who keep them supplied and drive their finished products to domestic markets and to ports. All these workers are therefore trade linked. Trade-linked employment can be estimated with the aid of input-output tables.

\section{B. Distinctions and Relationships}

The first three rows of Table 1 summarize the differences and relationships between the three measures.

First, tradable employment, trade-linked employment, and export-induced labor demand are attributes of different entities (Table 1, row 1). As discussed, tradability is an attribute of products, industries and workers, and tradable employment is measured in number of workers. Conversely, only a task can be export induced; a worker cannot, as workers often supply labor to meet demand in export markets some of the time, and in domestic markets the rest of the time. Trade-linked employment is a hybrid concept that combines counting workers and using the input-output tables. It cannot be a feature of an industry, because some workers in service industries upstream from tradable sectors do not sell services to the tradable sector (e.g., some workers in the trucking sector move household furniture and do not interact with shoe and racket factories). It is an idea developed to shed light on policies that influence human capital accumulation and labor regulations-neither of which are 
attributes of tasks (we train workers, and labor regulations do not vary according to the source of the final demand). Trade linkage is therefore most usefully treated as a feature of workers.

Second, the set of workers producing tradables is a subset of those who are trade linked (Table 1, rows 2 and 3). Every worker in a shoe or a tennis-racket factory produces tradables. All these workers, by definition, are trade linked, but so are those truckers that facilitate their production.

Finally, although trade-linked employment is a feature of workers, while export-induced labor demand is a feature of tasks, the two phenomena are nested in a different way. Any task that is performed to meet export demand must be performed by a worker who is, by definition, trade linked. After all, the fact that a trucker sometimes carries tennis rackets to port suffices to make him a tradelinked worker. A key logical result follows: so long as trade-linked workers put in as much time at work as nontrade-linked workers, the share of all person-hours worked that are export induced must be smaller than the share of all workers who are trade linked.

To reiterate: the three concepts are distinct. Two of them are features of workers and one of tasks, and the share of workers who are trade linked will be larger than both the fraction of workers who produce tradables, and (usually) the fraction of labor demand that is induced by exports.

\section{Relevance of Particular Measures to Particular Policy Discussions}

We now return briefly to the three policy debates discussed in the introduction. Each of them has been influenced by the idea that employment has globalized in some way, and each of them, we contend, explicitly or implicitly invokes a distinct measure of internationally interconnected labor. We emphasize that we do not necessarily endorse the assumptions and terminologies that underlie the debates themselves. Our only claim is that these policy debates occur, and that the tradeoffs being debated depend upon the interconnections we attempt to measure in this paper.

Macroeconomists care about export-induced labor demand because it can increase a government's incentive to free ride on other countries' efforts to stimulate their economies (e.g., Prasad and Sorkin 2009, Cwik and Wieland 2011, and comments by various governments around the 2009 G20 meetings). Thus, high levels of EILD create a rationale for international coordination of fiscal policy. Levels of tradable or trade-linked employment are not relevant to this argument. After all, a country's incentive to free ride is totally unrelated to the employment level in its import-competing sectors (e.g., its shoe factories), which is included in both tradable and trade-linked employment. Similarly, employment upstream from import-competing sectors (e.g., truckers transporting domestically produced shoes to local markets), which is included in trade-linked employment, does not add to incentives to free ride. 
Table 1: Distinguishing Our Three Notions of Internationally Interconnected Labor Markets

\begin{tabular}{|c|c|c|c|}
\hline & $\begin{array}{l}\text { Export-Induced } \\
\text { Labor Demand }\end{array}$ & Tradable Employment & Trade-Linked Employment \\
\hline This is a feature of... & Tasks & \multicolumn{2}{|c|}{ Workers } \\
\hline $\begin{array}{l}\text { What/who is } \\
\text { included? }\end{array}$ & $\begin{array}{l}\text { Tasks undertaken to produce } \\
\text { products for sale to } \\
\text { foreigners }\end{array}$ & $\begin{array}{l}\text { Workers producing tradables } \\
\text { (goods and services that } \\
\text { could be produced or sold in } \\
\text { other countries). }\end{array}$ & $\begin{array}{l}\text { Workers producing tradables... } \\
\text { plus... } \\
\text {.. workers employed in sectors } \\
\text { that produce nontradable } \\
\text { services used in production by } \\
\text { tradable sectors. }\end{array}$ \\
\hline For example: & $\begin{array}{l}\text { Labor demanded from } \\
\text { racket factory workers to } \\
\text { make those rackets that } \\
\text { are exported; } \\
\text { Labor demanded from } \\
\text { truckers to transport } \\
\text { these rackets to port. }\end{array}$ & $\begin{array}{l}\text { Workers in tennis racket } \\
\text { or shoe factories }\end{array}$ & $\begin{array}{l}\text { Workers in tennis racket or } \\
\text { shoe factories } \\
\text { - Those truckers who serve } \\
\text { these factories }\end{array}$ \\
\hline $\begin{array}{l}\text { What is not } \\
\text { included? }\end{array}$ & $\begin{array}{l}\text { Tasks undertaken to serve } \\
\text { domestic markets }\end{array}$ & $\begin{array}{l}\text { Workers producing } \\
\text { nontradables. }\end{array}$ & $\begin{array}{l}\text { Those workers producing services } \\
\text { that are neither tradable nor } \\
\text { auxiliary to the production of } \\
\text { tradables. }\end{array}$ \\
\hline For example: & $\begin{array}{l}\text { - Labor demanded from } \\
\text { factory workers to } \\
\text { produce shoes and those } \\
\text { rackets that are sold } \\
\text { domestically; } \\
\text { - Labor demanded from } \\
\text { truckers to transport } \\
\text { shoes or tennis rackets to } \\
\text { local markets. } \\
\text { Labor demanded from } \\
\text { truckers to help local } \\
\text { people move house. }\end{array}$ & - All truck drivers & $\begin{array}{l}\text { - Those truck drivers who } \\
\text { specialize in serving local } \\
\text { consumers (e.g., moving } \\
\text { companies) }\end{array}$ \\
\hline $\begin{array}{l}\text { This measure is } \\
\text { important because } \\
\text { it sheds light on }\end{array}$ & $\begin{array}{l}\text {... the importance of } \\
\text { coordinating stimulus policy } \\
\text { internationally. }\end{array}$ & $\begin{array}{l}\ldots \text { the welfare effects of } \\
\text { exchange rate policies. }\end{array}$ & $\begin{array}{l}\text {... the importance of pro- } \\
\text { competitive human resource } \\
\text { policies. }\end{array}$ \\
\hline
\end{tabular}

Source: Authors.

Lower exchange rates can help promote exports and discourage imports, which should help manage international payments imbalances. However, they are also understood to be redistributive, boosting employment or earnings in tradable sectors, while reducing household purchasing power. They therefore become relatively attractive when the share of workers producing tradables for a living is high. ${ }^{6}$ These arguments about the redistributive effects of currency movements do not hinge on export-induced employment. Cheaper currencies improve the fortunes of rice farmers relative to those of barbers in countries that export rice (e.g., Thailand) just as they do in countries that import it

6 Devaluations can of course have other effects on welfare, but these two are the main channels discussed in policy circles (Frieden 2014). 
(e.g., the Philippines). ${ }^{7}$ Thus, the argument is not about exports. The argument does not turn strongly on trade-linked employment either. Even those truck drivers who transport rice between farms and markets or ports, and are therefore auxiliary to agricultural production, are more likely than farmers to be hurt by a currency devaluation. This is because truckers' earnings are more likely set in local markets than are those of farmers. ${ }^{8}$

We devised our measure of trade-linked employment to shed light on how relevant arguments for pro-competitive education and labor relations policies might be, given the composition of employment. Export-linked labor demand and tradable employment shares would both systematically underestimate the number of workers whose pay and productivity could imperil trade competitiveness, because higher costs in import-competing industries and upstream from them matter too.

\section{RESULTS}

\section{A. Export-Induced Labor Demand}

We estimate the shares of labor demand that are export induced by combining the National InputOutput Table (NIOT) with data on employment by sector from the 2014 World Input-Output Database Socio-Economic Accounts (WIOD). Both databases are sourced from the World InputOutput Database. ${ }^{9}$ We make these estimates separately for each country and year. We use these data in the usual way to estimate export-linked demand for labor in each of 35 sectors of each economy, as the gross sales required from that sector to meet demand for the country's exports, multiplied by the average labor requirement per unit of sales for that sector. Dividing export-linked labor demand in sector $i\left(l_{x, i}\right)$ by total sectoral labor demand $\left(l_{i}\right)$ yields the share of labor demand in the sector that is export induced $\left(\lambda_{i}\right)$. The equations involved are presented in Appendix 1. If we denote aggregate (i.e., economywide) labor demand by $l \equiv \sum l_{i}$ and total export-linked labor demand by $l_{x} \equiv \sum l_{x, i}$, then the aggregate export-induced labor demand share (henceforth, EILD) is simply $\lambda \equiv l_{x} / l$.

7 We recognize that the example of farmers and barbers paints a somewhat oversimplified picture, insofar as those producers of tradables and nontradables who are not self-employed sometimes receive similar wages. However, in this case (and again through the lens of the types of basic model invoked in policy circles), a currency devaluation, other things equal, would lead to more jobs in shoe and racket factories while driving down the real purchasing power of wages in all three sectors. In other words, the pain would be unequally distributed, with nontradables workers seeing only the downside of the devaluation, and tradables workers loss of purchasing power at least partially offset by gains in employment. The point remains: in most textbook trade models, a devaluation hurts more people if more people produce nontradables, whether this pain is felt on the quantity or on the wage axis.

8 We have been asked whether in those rare instances in which truckers can operate freely across borders (a form of shortterm migration) this could, in theory result in truck drivers' earnings being set in world markets. This is unlikely outside the European Union. Cabotage, transporting goods or passengers from point to point within a country of which one is not a citizen, is prohibited under most nation's laws. The members of the European Union are exceptional in permitting cabotage in aviation, shipping, and road transport. A few other exceptions exist, wherein cabotage is permitted through bilateral treaties, such as those between Australia and New Zealand. However, even NAFTA's transportation provisions, if fully implemented, would not grant any cabotage rights.

9 WIOD. http://www.wiod.org/home. 
Figure 1: The Percentage of Labor Demand that Is Export Induced

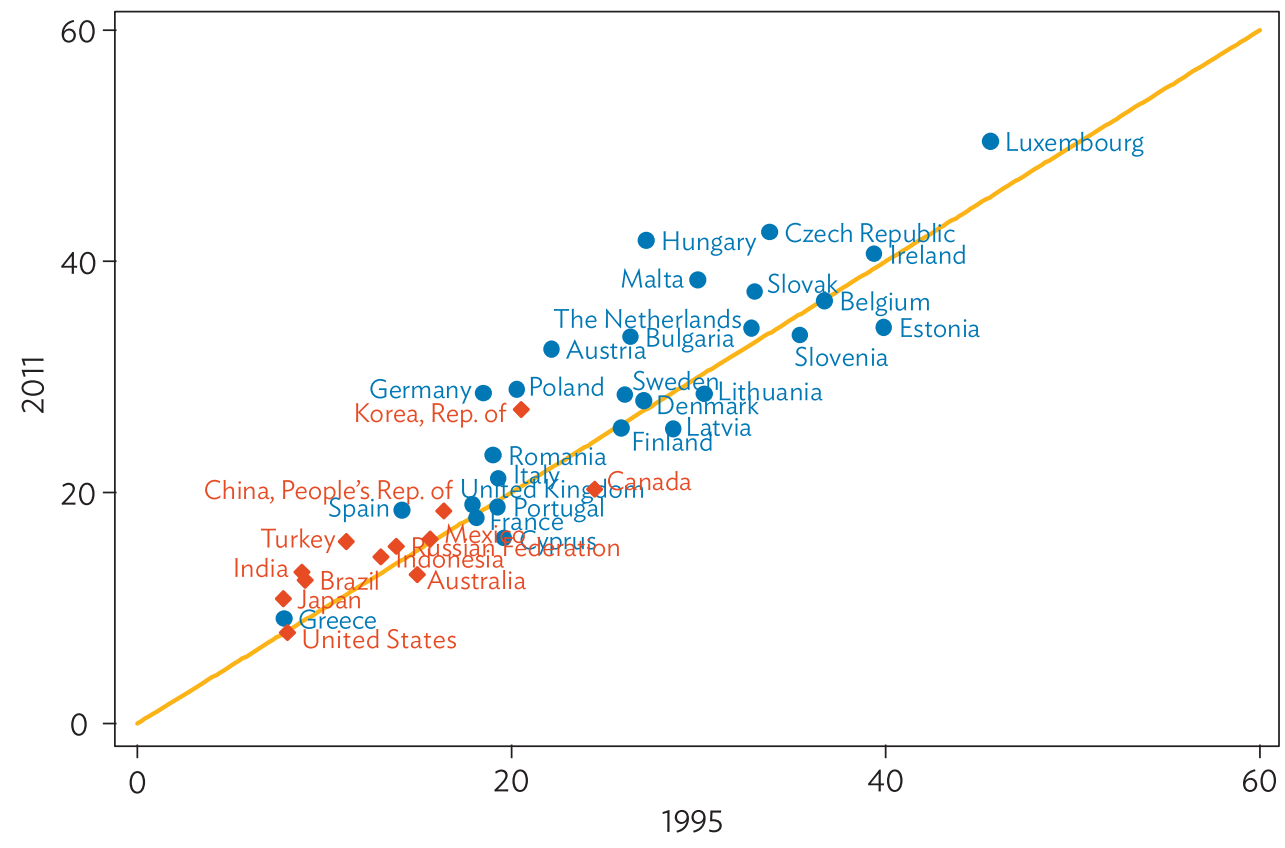

Notes: Calculations of export-induced labor demand shares are explained in the text and Appendix 1. Diagonal line is $y=x$. Non-European Union countries are marked by diamonds.

Source: Authors' calculations using data from the World Input-Output Database.

Figure 1 provides estimates of EILD in 1995 and 2011 for the 40 WIOD countries. These are the earliest and latest years in which all the necessary data are available from the WIOD. The figure provides a 45-degree line separating countries where EILD rose from those where it fell. It also distinguishes European Union (EU) from non-EU countries. Perusal of these estimates suggests three hypotheses:

H1: EU members are more export linked. Other than two early industrializers-Taipei,China and the Republic of Korea, all other high EILD countries are EU members.

H2: Size matters. Countries with large domestic markets (e.g., US, Japan, Brazil, India, Indonesia, Russian Federation) tend to have less export-linked labor demand.

H3: Per capita income levels are not strongly correlated with export linkages.

These hypotheses are intuitive. The EU is a common market $(\mathrm{H} 1)$. Countries with fewer overall domestic consumers must tap export markets to exploit economies of scale (H2). And high incomes are correlated with a sophisticated export mix, encouraging export-induced employment, but also with higher wages, which counterbalances it. 
Table 2 tests these hypotheses. The columns provide the results when EILD for a particular year is regressed, separately for 1995 and 2011, on a dummy variable for EU membership (to test H1), the logarithms of population and gross domestic product (GDP) (H2), and the logarithm of GDP per capita $(\mathrm{H} 3) .^{10}$

Table 2: The Correlates of Export-Induced Labor Demand

\begin{tabular}{|c|c|c|c|c|c|c|}
\hline & (1) & (2) & (3) & (4) & (5) & (6) \\
\hline \multicolumn{7}{|l|}{ A. Results in 1995} \\
\hline \multirow[t]{2}{*}{ EU member dummy } & $12.85^{* * *}$ & & & & 3.73 & 3.76 \\
\hline & $(2.260)$ & & & & $(2.602)$ & $(2.665)$ \\
\hline \multirow[t]{2}{*}{ Population (in logs) } & & $-3.90^{* * *}$ & & & $-3.43^{* * *}$ & \\
\hline & & $(0.633)$ & & & $(0.829)$ & \\
\hline \multirow[t]{2}{*}{ InGDP_PPP } & & & $-4.00^{* * *}$ & & & $-3.39^{* * *}$ \\
\hline & & & $(0.611)$ & & & $(0.808)$ \\
\hline \multirow[t]{2}{*}{ Per capita GDP (in logs) } & & & & 2.14 & -0.74 & 1.59 \\
\hline & & & & $(1.348)$ & $(0.795)$ & $(0.979)$ \\
\hline \multirow[t]{2}{*}{ Constant } & $13.62^{* * *}$ & $87.75^{* * *}$ & $127.06^{* * *}$ & 2.02 & $84.48^{* * *}$ & $93.44^{* * *}$ \\
\hline & $(1.470)$ & $(11.001)$ & (16.432) & $(12.547)$ & $(16.790)$ & $(18.603)$ \\
\hline Observations & 39 & 39 & 39 & 39 & 39 & 39 \\
\hline R-squared & 0.370 & 0.571 & 0.519 & 0.055 & 0.591 & 0.589 \\
\hline \multicolumn{7}{|l|}{ B. Results in 2011} \\
\hline \multirow[t]{2}{*}{ EU member dummy } & $14.00^{* * *}$ & & & & $6.72^{*}$ & $7.24^{* *}$ \\
\hline & $(2.332)$ & & & & $(3.327)$ & $(3.359)$ \\
\hline \multirow[t]{2}{*}{ Population (in logs) } & & $-3.64^{* * *}$ & & & $-2.63^{* * *}$ & \\
\hline & & $(0.666)$ & & & $(0.953)$ & \\
\hline \multirow[t]{2}{*}{ InGDP_PPP } & & & $-3.84^{* * *}$ & & & $-2.49^{* x}$ \\
\hline & & & $(0.746)$ & & & $(0.974)$ \\
\hline Per capita GDP (in logs) & & & & $\begin{array}{r}3.01^{*} \\
(1.710)\end{array}$ & $\begin{array}{r}-0.65 \\
(1.160)\end{array}$ & $\begin{array}{r}0.86 \\
(1.346)\end{array}$ \\
\hline \multirow[t]{2}{*}{ Constant } & $15.36^{* * *}$ & $86.30^{* * *}$ & $128.85^{* * *}$ & -4.99 & $71.08^{* * *}$ & $78.71^{* * *}$ \\
\hline & $(1.408)$ & $(11.744)$ & $(20.807)$ & $(16.582)$ & $(20.382)$ & $(24.608)$ \\
\hline Observations & 39 & 39 & 39 & 39 & 39 & 39 \\
\hline R-squared & 0.380 & 0.445 & 0.400 & 0.064 & 0.489 & 0.474 \\
\hline
\end{tabular}

$\mathrm{EU}=$ European Union, GDP = gross domestic product, $\mathrm{PPP}=$ public-private partnership.

Notes: Dependent variable is the percentage (0-100) of labor demand that is export induced. Robust standard errors in parentheses. ${ }^{*} p<0.10,{ }^{* *} p<0.05,{ }^{* * *} p<0.01$.

Source: Authors' calculations.

The bivariate regression results indicate that EU membership and domestic market size play a major role in driving EILD (columns 1-3), while per capita incomes play a smaller role (column 4). Multivariate regression results confirm this (columns 5-6). Focusing on the fifth and sixth regressions

10 We use purchasing power parity (PPP) corrected estimates for GDP, but not for per capita GDP, because the purchasing power considerations that drive $\mathrm{H} 2$ require PPP corrections, while the competitiveness considerations that drive $\mathrm{H} 3$ do not. 
in each panel (which in turn drop population and GDP to avoid estimation of near tautologies), we confirm the statistical importance of size and institutions, but not that of per capita income. These regressions also suggest that the effects of EU membership on EILD have grown over time, especially relative to those of market size."

Next, we analyze shifts in EILD. If we denote each sector's share of total labor demand by $\alpha_{i}$, (aggregate) EILD is simply the employment-weighted average of each sector's shares of sectoral employment that is export linked:

$$
\lambda \equiv \frac{l_{x}}{l} \equiv \sum_{i} \frac{l_{x, i}}{l} \equiv \sum_{i} \frac{l_{i}}{l} \frac{l_{x, i}}{l_{i}} \equiv \sum_{i} \alpha_{i} \lambda_{i}
$$

The change in EILD can then be decomposed over time as:

$$
\Delta \lambda \equiv \sum_{i} \alpha_{i} \Delta \lambda_{i}+\sum_{i} \lambda_{i} \Delta \alpha_{i}
$$

This is a standard between-within sector decomposition, amenable to the following interpretation, alluded to at the outset: the effects of large increases in export dependence within industries (the first summation) may have been counterbalanced by employment shifts out of the most export-linked industries (the second).

Figure 2 presents the results of this decomposition. ${ }^{12}$ Economies are ranked in descending order by the change in EILD. While labor demand became more export induced in 28 economies (Hungary-Mexico), it became less export induced in 12 (US-Estonia). Moreover, EILD increased fairly slowly in many of the 28 economies in which it rose-to pick two arbitrary cutoffs, EILD increased by fewer than 3 percentage points in 11 of these 28 economies; and by fewer than 5 percentage points in 19 of the 28. This does not constitute evidence of a dramatic increase in export dependence of labor demand.

The decomposition accounts for weak growth in EILD. All but two large commodity dependent countries (Australia and Canada) saw significant internationalization of supply chains within sectors. ${ }^{13}$ Thus, sector specialists are correct to report that their sectors are growing rapidly more reliant on exports for job creation. However, labor demand has gradually shifted from more to less export-linked sectors as economies have deindustrialized, moved workers out of agriculture, and shifted into services, reducing the rate at which export dependence grew. Indeed, all the economies experiencing reductions in EILD are advanced economies, and the only ones to see significant increases in EILD (Austria; Germany; the Republic of Korea; and Taipei,China), have pursued industrial policies to retain footholds in foreign goods markets.

${ }^{11}$ The size of the coefficients in these regressions (columns 5-6) tells a similar story. In 2011, EILD was approximately 7 percentage points higher in EU countries than in non-EU countries - ceteris paribus, up from under 4 percentage points in 1995. Differences projected based on population are also large: the US's larger population, relative to Denmark's, predicts that the former's EILD should have been 10.1 points lower than Denmark's in 2011, while its larger GDP predicts that its EILD should have been 10.3 percentage points lower than Denmark's. Per capita income has unstable and insignificant effects.

12 The detailed static and dynamic decomposition tables corresponding to identities (1) and (2) are too large to present. They are available on request.

13 In Australia, EILD fell because agriculture became more focused on meeting domestic demand. In Canada, the culprit was a decline in each manufacturing subsector's reliance on export demand, as the economy caught the resource curse and the Canadian dollar appreciated. 
Figure 2: Decomposing the Changes in Export-Linked Labor Demand, 1995-2011

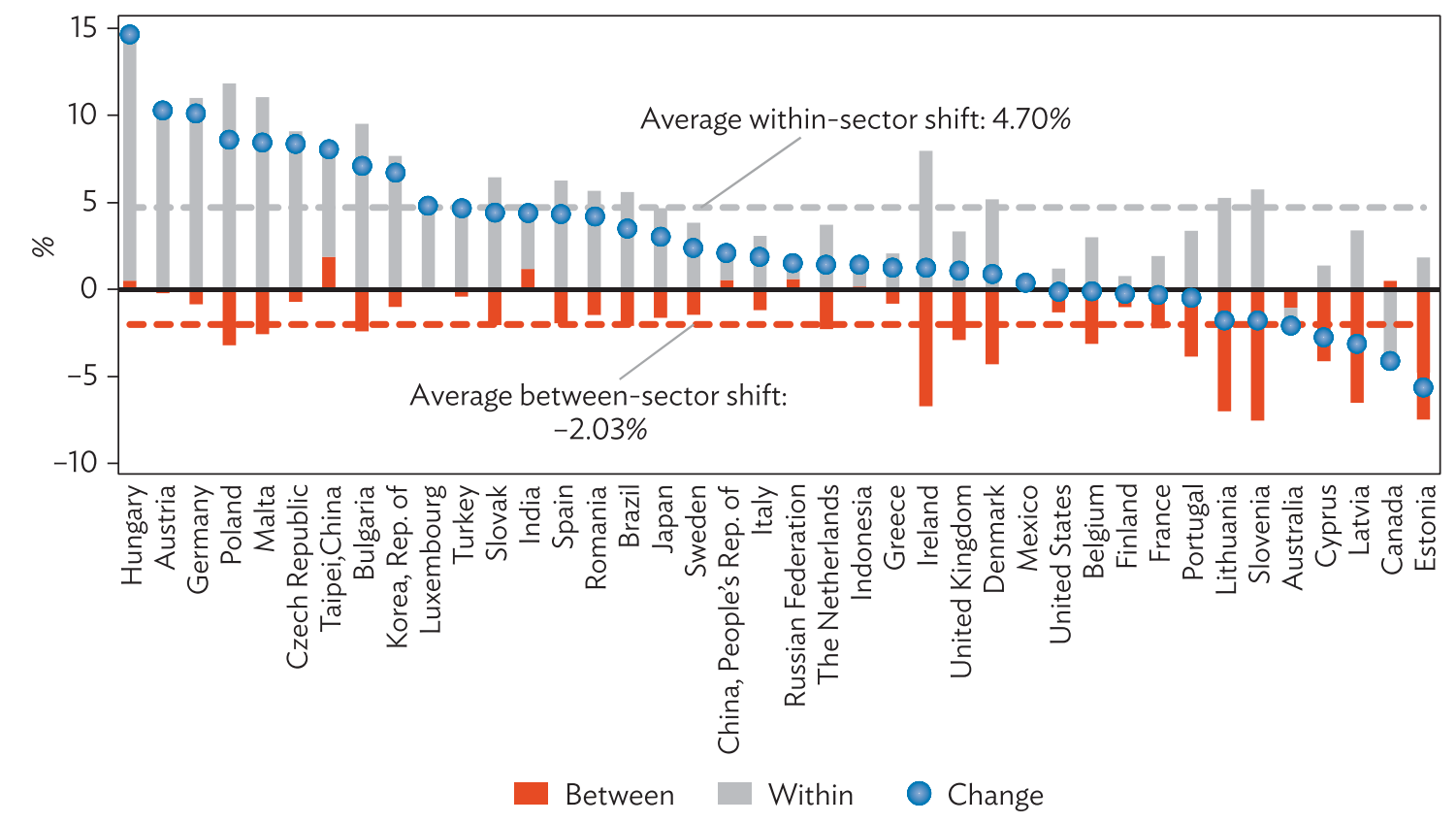

Source: Authors' calculations using data from the World Input-Output Database.

\section{B. Tradable Employment}

To characterize trends in the share of employment that is tradable, we introduce one further distinction: absent policy intervention, a product that might be tradable may in fact be rendered nontradable by policies. For example, although cars are intrinsically tradable (they have been traded across some national borders for decades), in the past, import restrictions have rendered them de facto nontradable in many countries. Similarly, food grains are often rendered de facto nontradable by export restrictions. The claim regarding globalization is not simply that technological change pushed more jobs from the intrinsically nontradable category into the intrinsically tradable category (although this is a key argument in the literature on tradability of services-see Friedman 2005 and Blinder 2006). Rather, it is that institutional and policy changes, most importantly trade liberalization, made products that had always been intrinsically tradable de facto tradable as well. We will deal with this problem in two phases. We will begin by characterizing trends in employment in intrinsically tradable sectors, showing that the share has trended downwards almost everywhere in recent decades. We will then use this to bound de facto tradable employment. The key, if obvious, insight that we will exploit to do this is that a job cannot be de facto tradable unless it is intrinsically tradable.

\section{Employment in Intrinsically Tradable Sectors}

It is not possible to identify intrinsically tradable sectors using the data available without heroic assumptions. Instead of providing point estimates, we therefore provide lower and upper bound estimates of intrinsically tradable employment in as many years as possible. Whenever the lower bound at some initial moment in time was higher than the upper bound at a later moment in time, we 
will confidently assert that the share of employment in intrinsically tradable sectors declined. Conversely, if the initial upper bound estimate was lower than the subsequent lower bound estimate, we would confidently assert that the share of employment in intrinsically tradable sectors increasedbut this never happens.

We derive our lower bound by counting all employment in goods producing sectors (agriculture, fisheries, forestry, mining, quarrying, and manufacturing) as intrinsically tradable, and all services as intrinsically nontradable. This underestimates the level of tradable employment at any moment in time, because some services are tradable. It also underestimates the trend over time in the share of employment that is in intrinsically tradable sectors, because technology has rendered some services intrinsically tradable that were not so before (Jensen 2011).

Our upper bound estimate draws on Jensen et al.'s (2005) work on the spatial clustering of services establishments in the US. ${ }^{14}$ Jensen and Kletzer argue that domestically nontradable services must be produced close to customers, and so will tend to be widely dispersed around the country, while domestically tradable services can exploit the agglomeration economies and economies of scale that come from clustering far from the final consumer. This permits them to explore the tradability of a highly disaggregated set of subindustries using the 2000 Decennial Census of Population Public Use Micro Sample (IPUMS files). To ensure that our results using ILO, Groningen Growth and Development Centre's (GGDC), and WIOD data use estimates of services tradability that are in principle compatible, we make our estimates of tradable employment first for the WIOD and then aggregate them up to the 1-digit classification used by the ILO and GGDC. ${ }^{15}$ Appendix 4 provides upper bound estimates of the fractions of employment in each WIOD sector and each 1-digit ISIC sector that are assumed to be tradable for our upper bound estimates.

We take these estimates, based on US clustering of industries, as our upper bound for the fraction of employment that is intrinsically tradable in each of these nine sectors in every country. This assumption is justified as follows. First, following the logic of New Trade Theory (Krugman 1991), any industry is more likely to be clustered within the US than it is to be tradable across international borders. This is because transport costs within the US are generally lower than transport costs between nations; and because taxes, legal, informational, logistical and other costs of crossing borders between US states are likely lower than the corresponding costs of traversing international borders. It follows that services that are intrinsically tradable internationally are extremely likely to be clustered in the US. Second, many service activities that the spread of internet made possible to offshore (e.g. call centers,

14 We have been asked whether this argument applies to, for example, a chef from France or a professor from the US, serving in a restaurant or college in Beijing, given that they are paid wages similar to those in their countries of origin. It usually does: these workers provide a service that cannot be produced at a distance from consumers, and the service itself is priced for the local market. If their salaries are specified in yuan, then they will not stretch as far if the yuan depreciates. If their salaries are specified in dollars, the argument applies partially and in the longer run, as their purchasing power will not decline immediately, in response to a depreciation but it becomes more likely that they will be fired or denied raises in future.

15 We drew on Spence and Hlatshwayo (2011) to do this. Their Appendix II provides estimates of tradability based on Jensen and Kletzer's estimates of tradability by two-digit 2000 census codes. Wherever the Spence and Hlatswayo sectors map cleanly onto the 35-sector classification used in the WIOD data, we used their estimates of tradability. We constructed a many-to-one mapping from the census sectors to the remaining WIOD sectors. We then treated each census sector with medium or high geographic concentration as tradable, and calculated the share of employment in each WIOD sector (in the US in 2000) that belongs to tradable census sectors. We also aggregated up from the WIOD to the one-digit codes using US employment data from the WIOD. Full details of the procedure are available on request. 
logistics) were already being delivered across US state lines in 2000. Third, the employment shares of the most tradable service subsectors in the US economy are likely to be higher than elsewhere. ${ }^{16}$

For maximum country coverage, we carefully cleaned the longest available set of ILO data (LABORSTA), yielding usable employment series for 68 countries, covering about $73 \%$ of the world's population from 1970 until 2008. For more temporal coverage, we use the GGDC's 10-sector database, covering 43 countries over variable periods spanning 1947-2013. Cleaning procedures appear in Appendix 2. Results using GGDC data are fully consistent with those reported here, and appear in Appendix 3.

Figures 3 and 4 illustrate our approach. In 1970, 65.5\% of the Republic of Korea's employed labor force worked in goods-producing sectors, and no more than $68.4 \%$ worked in sectors producing either goods, or services that would be considered tradable in the US by the year 2000. These figures fell to $24 \%$ and $38.3 \%$ by 2008 . Because the lower bound in 1970 is higher than the upper bound in 2008, we can assert with confidence that the fraction of Korean workers employed in intrinsically tradable sectors declined. No such confidence is possible in Iceland, where our series begins in 1991 with lower and upper bound estimates of $27.5 \%$ and $39.6 \%$ respectively, but end in 2008 at $16.2 \%$ and $32 \%$ respectively. Employment- producing goods fell in Iceland, but we cannot rule out the possibility that employment in intrinsically tradable services grew fast enough to compensate for this.

Figure 3: Intrinsically Tradable Employment in the Republic of Korea

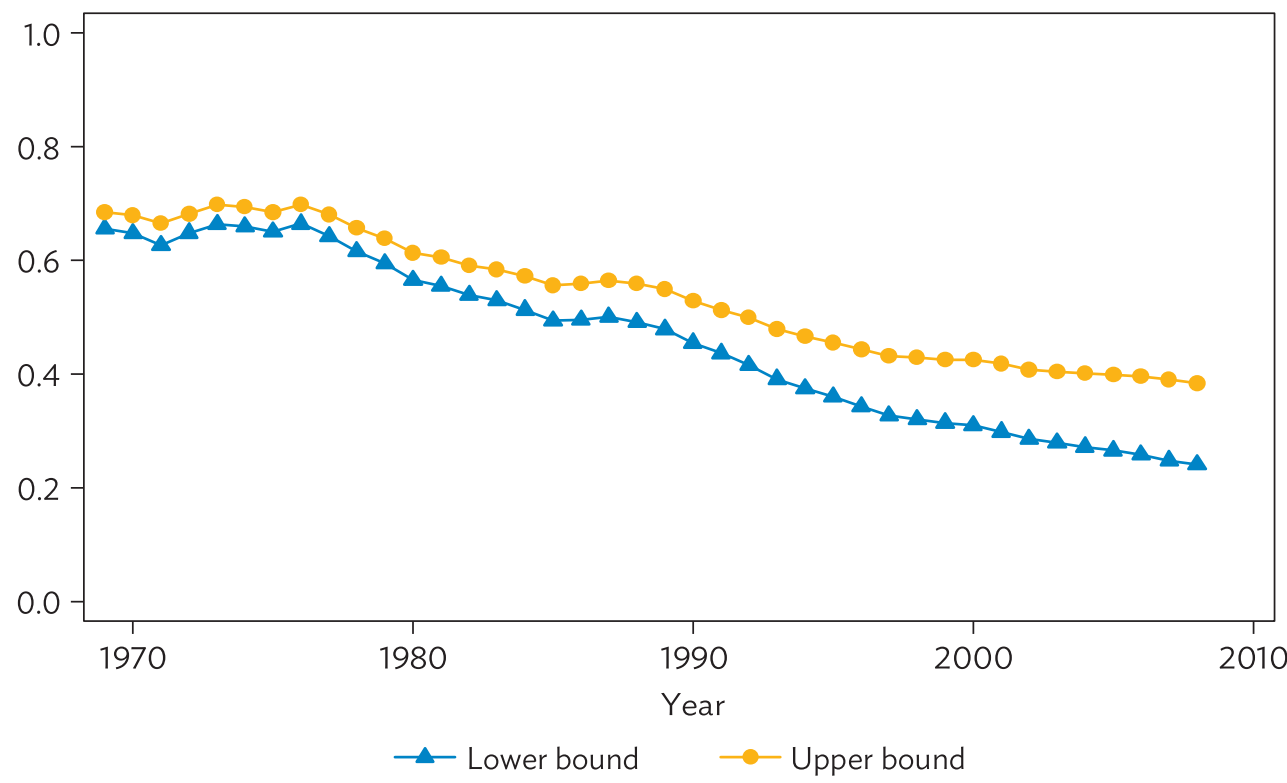

Note: Lower bound assumes only goods are tradable. Upper adds tradable services drawing on Spence and Hlatshwayo (2011). Source: Authors' calculations using data from the International Labour Organization, Groningen Growth and Development Centre, and World Input-Output Database.

16 Jensen et al.'s (2005) methodology has been criticized for potentially misidentifying industries that are merely urban, as tradable (Blinder 2009). This possibility actually works to our advantage when using their estimates to derive upper bounds on tradability. 
Figure 4: Intrinsically Tradable Employment in Iceland

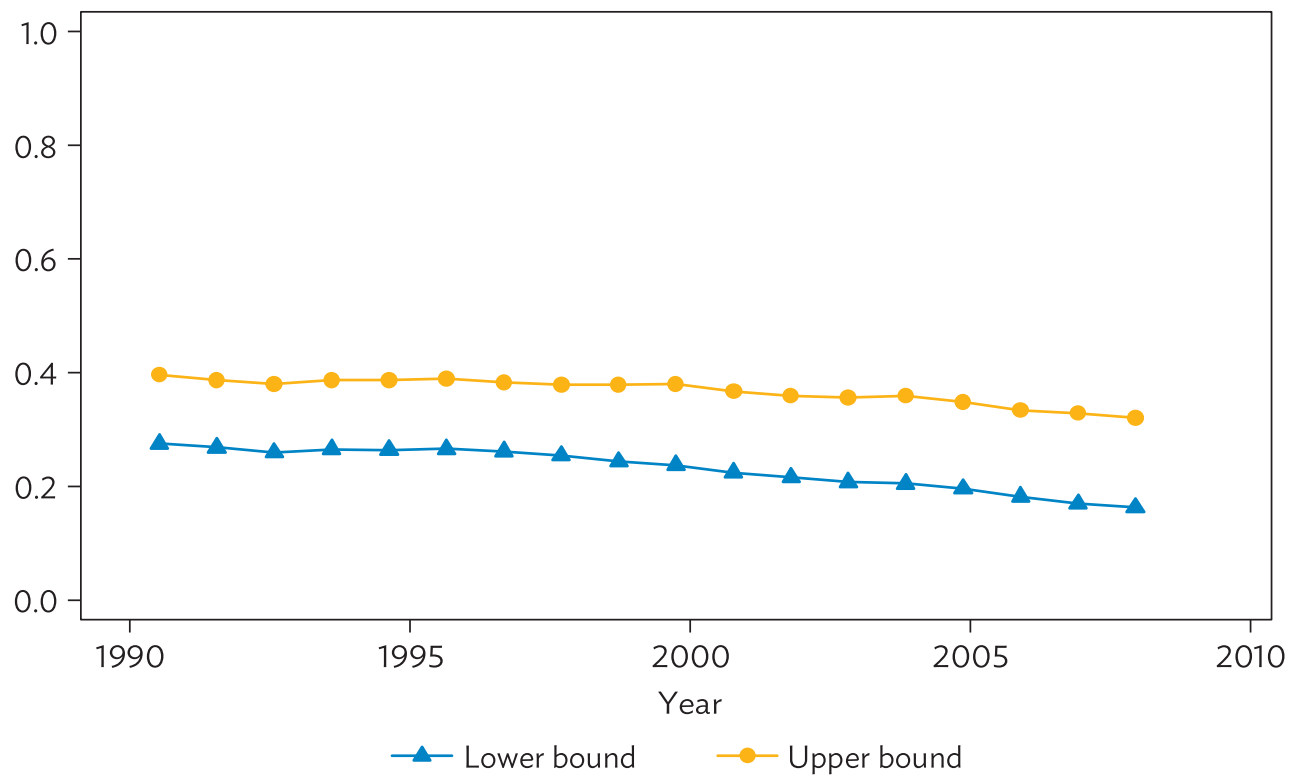

Note: Lower bound assumes only goods are tradable. Upper adds tradable services drawing on Spence and Hlatshwayo (2011).

Source: Authors' calculations using data from the International Labour Organization, Groningen Growth and Development Centre, and World Input-Output Database.

The Korean and Icelandic cases are helpful in three other respects. First, they demonstrate something that we will demonstrate holds in every Organisation for Economic Co-operation and Development country-namely that the upper and lower bound estimates of intrinsically tradable employment both fall in the $15 \%-40 \%$ range by the late 2000 s.

Second, they suggest that employment in intrinsically tradable services has risen quite dramatically, especially at early stages of development. This figure, which is the gap between our upper and lower bound estimates of intrinsically tradable employment, expanded from $2.9 \%$ (68.4\%-65.5\%) in 1970 to $14.3 \%$ by 2008 in the Republic of Korea, and from $12.1 \%$ to $15.8 \%$ in Iceland. This is why the possibility that intrinsically tradable employment has risen must be taken seriously: in employment terms, tradable services may have grown faster than agriculture and manufacturing have shrunk.

Third, they impress on us that the results of the bounds analysis may not be comparable across countries, as the time periods for which we have employment data vary across countries. The fact that we see an unambiguous decrease in intrinsically tradable employment in the Republic of Korea but not Iceland might simply reflect the fact the Icelandic data do not go back far enough. Analysis of the GGDC dataset, which covers a different and smaller set of countries over a longer time period, solves this problem.

We are attentive to concerns about manufacturing firms' increased outsourcing of intermediate service activities to other domestic firms. This could lead our upper and lower bound measures to register spuriously large declines (Tregenna 2010; Kakaomerlioglu Cetindamar, and Carlsson 1999). Nevertheless, our upper bound should still overestimate tradable employment outside 
the US. For one thing, outsourcing of producer services by manufacturing firms is a process that had likely progressed further in the US than in most countries. ${ }^{17}$ Moreover, production services that are auxiliary to manufacturing do cluster geographically around manufacturing firms (Kakaomerlioglu, Cetindamar, and Carlsson 1999), so that those productive services subsectors receiving the jobs tend to be classified as tradable in our upper bound. Thus, even while increases in outsourcing probably cause the "true" intrinsically tradable employment share to move further from the lower bound estimate and closer to the upper bound estimate as time goes on, a later upper bound that is below the earlier lower bound can be taken to indicate a decline in intrinsically tradable employment.

To summarize what our bounds analysis tells us about trends around the world, we first estimate separately the slopes of lower- and upper-bound lines for each of our countries. Then, we classify countries according to whether these series suggest that they have globalized, deglobalized, or fall into an ambiguous category. Acknowledging that the conventional wisdom is that work is globalizing, we use a classification scheme that errs in favor of finding that employment in each country has either globalized or has an ambiguous trend. Thus, we conclude that a country "deglobalized" in terms of the intrinsic tradability of employment if two conditions are met: (i) the slopes of both the upper and lower bound series are negative and statistically significant (at the 5\% significance level); and (ii) the earliest lower bound estimate is higher than the subsequent upper bound estimate (e.g., the Republic of Korea). We deem countries for which the initial upper bound is lower than the subsequent lower bound to have "globalized." The rest (e.g., Iceland) are "ambiguous."

Table 3 summarizes the results for our sample of 68 economies based on the ILO data and utilizes these to classify each economy as globalizing, deglobalizing or ambiguous over this period. The economies are arranged by region, and the regions are arranged in rough descending order by per capita income. The results reveal a general hierarchy across levels of development, with intrinsically tradable employment shares generally in a much higher range amongst the less developed economies. This mostly reflects the well-understood fact that richer economies have lower agricultural employment shares, and also that economies that industrialized earlier are today richer and also had higher manufacturing employment shares (Felipe, Mehta, and Rhee 2018).

This negative cross-sectional association between economic development and intrinsically tradable employment is also apparent within countries over time. The growth rates of the lower bound estimates (excluding tradable services) or the upper bound estimates (including tradable services) are negative in almost every country, and 50 countries, capturing $94 \%$ of the population represented by our data deglobalized in the period for which we have data. The remaining 18 countries, which account for the other $6 \%$ of the represented population, fall in the ambiguous category. Perhaps unsurprisingly, many of the countries in the ambiguous category are either advanced or island economies (Australia, Bahamas, Canada, The Dutch Antilles, Finland, Iceland, Israel, Montserrat, New Zealand, and San Marino), with the low agricultural and manufacturing employment levels that come respectively with higher wages or physical distance. Others among these 18 belong to the former Communist bloc with short time series that begin in the 1990s (Azerbaijan, Hungary, the Kyrgyz Republic, and Mongolia).

17 The extent of domestic outsourcing is notoriously difficult to compare across countries (e.g., see Kakaomerlioglu, Cetindamar, and Carlsson 1999, Table 1). However, the view that outsourcing of manufacturing activity to service firms was most advanced by the turn of the century in liberal market economies like the US is standard in work on the varieties of capitalism (Soskice and Hall 2001), US labor relations (Brown, Eichengreen, and Reich 2009), and firm strategy (Berger 2005). Similarly, Baumol, Blinder, and Wolff (2003), document rapid downsizing in US manufacturing and upsizing in nonmanufacturing starting in 1987, and link this to the US's exceptionally rapid political and institutional shift to the right. 
The remaining countries in the ambiguous category have experienced relatively limited exit from agriculture (Bangladesh, Myanmar, and Nicaragua). ${ }^{18}$

Finally, if we focus on the richest economies (which can be found by starting with the Republic of Korea and working up the table-skipping Turkey), we see that the share of employment in intrinsically tradable sectors is under $40 \%$ in all of them. A reasonable description puts the range between the lower and upper bounds at 15\%-40\%.

18 Notwithstanding our efforts to clean the ILO data using a priori reasonable rules, the data from Botswana are suspect, with intrinsically tradable employment declining from the high 60\% range to the high 30\% range between 1985 and the mid1990 s, and then rising back up to $40 \%-50 \%$ by 2008. 
Table 3: Lower and Upper Bound Estimates of the Share of Employment that Is Intrinsically Tradable

\begin{tabular}{|c|c|c|c|c|c|c|c|c|c|c|c|c|}
\hline \multirow[b]{2}{*}{ Region } & \multirow[b]{2}{*}{ Economy } & \multicolumn{3}{|c|}{ Earliest Observation } & \multicolumn{3}{|c|}{ Latest Observation } & \multicolumn{2}{|c|}{ Lower Bound Slope } & \multicolumn{2}{|c|}{ Upper Bound Slope } & \multirow[b]{2}{*}{ Category } \\
\hline & & Year & $\begin{array}{l}\text { Lower } \\
\text { Bound }\end{array}$ & $\begin{array}{l}\text { Upper } \\
\text { Bound }\end{array}$ & Year & $\begin{array}{l}\text { Lower } \\
\text { Bound }\end{array}$ & $\begin{array}{l}\text { Upper } \\
\text { Bound }\end{array}$ & Coeff. & P-Value & Coeff. & P-Value & \\
\hline \multicolumn{13}{|c|}{ Western European and Others } \\
\hline & Australia & 1980 & $27.6 \%$ & $40.3 \%$ & 2008 & $14.8 \%$ & $32.9 \%$ & -0.005 & $(0.000)$ & -0.003 & $(0.000)$ & Ambiguous \\
\hline & Austria & 1983 & $38.7 \%$ & $50.2 \%$ & 2008 & $22.8 \%$ & $40.0 \%$ & -0.007 & $(0.000)$ & -0.004 & $(0.000)$ & Deglobalizing \\
\hline & Belgium & 1970 & $38.0 \%$ & $48.9 \%$ & 2008 & $18.3 \%$ & $36.8 \%$ & -0.005 & $(0.000)$ & -0.003 & $(0.000)$ & Deglobalizing \\
\hline & Canada & 1987 & $22.5 \%$ & $38.3 \%$ & 2008 & $15.8 \%$ & $34.9 \%$ & -0.002 & $(0.000)$ & -0.001 & $(0.006)$ & Ambiguous \\
\hline & Cyprus & 1976 & $44.6 \%$ & $54.0 \%$ & 1995 & $26.4 \%$ & $40.2 \%$ & -0.009 & $(0.000)$ & -0.007 & $(0.000)$ & Deglobalizing \\
\hline & Denmark & 1972 & $34.8 \%$ & $46.7 \%$ & 2008 & $17.8 \%$ & $35.1 \%$ & -0.004 & $(0.000)$ & -0.003 & $(0.000)$ & Deglobalizing \\
\hline & Finland & 1989 & $30.3 \%$ & $45.9 \%$ & 2008 & $21.8 \%$ & $40.3 \%$ & -0.004 & $(0.000)$ & -0.003 & $(0.000)$ & Ambiguous \\
\hline & France & 1969 & $42.2 \%$ & $52.2 \%$ & 2008 & $18.1 \%$ & $36.1 \%$ & -0.006 & $(0.000)$ & -0.004 & $(0.000)$ & Deglobalizing \\
\hline & Greece & 1981 & $50.5 \%$ & $60.6 \%$ & 2008 & $23.5 \%$ & $32.8 \%$ & -0.011 & $(0.000)$ & -0.009 & $(0.000)$ & Deglobalizing \\
\hline & Iceland & 1991 & $27.5 \%$ & $40.5 \%$ & 2008 & $16.2 \%$ & $32.8 \%$ & -0.007 & $(0.000)$ & -0.004 & $(0.000)$ & Ambiguous \\
\hline & Ireland & 1969 & $49.1 \%$ & $57.0 \%$ & 2008 & $18.7 \%$ & $36.2 \%$ & -0.008 & $(0.000)$ & -0.005 & $(0.000)$ & Deglobalizing \\
\hline & Italy & 1977 & $43.6 \%$ & $51.6 \%$ & 2008 & $24.5 \%$ & $41.8 \%$ & -0.006 & $(0.000)$ & -0.002 & $(0.000)$ & Deglobalizing \\
\hline & Luxembourg & 1970 & $42.5 \%$ & $52.2 \%$ & 2006 & $10.7 \%$ & $39.4 \%$ & -0.010 & $(0.000)$ & -0.003 & $(0.000)$ & Deglobalizing \\
\hline & The Netherlands & 1969 & $34.8 \%$ & $46.3 \%$ & 2008 & $14.3 \%$ & $33.5 \%$ & -0.005 & $(0.000)$ & -0.003 & $(0.000)$ & Deglobalizing \\
\hline & New Zealand & 1986 & $31.6 \%$ & $44.1 \%$ & 2008 & $19.8 \%$ & $36.4 \%$ & -0.005 & $(0.000)$ & -0.003 & $(0.000)$ & Ambiguous \\
\hline & Norway & 1972 & $36.6 \%$ & $46.6 \%$ & 2008 & $15.8 \%$ & $32.0 \%$ & -0.006 & $(0.000)$ & -0.004 & $(0.000)$ & Deglobalizing \\
\hline & Portugal & 1974 & $60.8 \%$ & $66.5 \%$ & 2008 & $29.4 \%$ & $41.7 \%$ & -0.009 & $(0.000)$ & -0.008 & $(0.000)$ & Deglobalizing \\
\hline & San Marino & 1978 & $43.2 \%$ & $47.5 \%$ & 2008 & $29.4 \%$ & $46.7 \%$ & -0.005 & $(0.000)$ & -0.002 & $(0.004)$ & Ambiguous \\
\hline & Spain & 1969 & $58.1 \%$ & $64.6 \%$ & 2008 & $19.7 \%$ & $36.5 \%$ & -0.010 & $(0.000)$ & -0.007 & $(0.000)$ & Deglobalizing \\
\hline & Sweden & 1969 & $39.2 \%$ & $50.9 \%$ & 2008 & $16.7 \%$ & $36.2 \%$ & -0.005 & $(0.000)$ & -0.003 & $(0.000)$ & Deglobalizing \\
\hline & Switzerland & 1969 & $46.5 \%$ & $55.5 \%$ & 2008 & $19.9 \%$ & $38.7 \%$ & -0.008 & $(0.000)$ & -0.005 & $(0.000)$ & Deglobalizing \\
\hline & Turkey & 1988 & $62.8 \%$ & $68.0 \%$ & 2004 & $51.9 \%$ & $59.1 \%$ & -0.008 & $(0.000)$ & -0.006 & $(0.000)$ & Deglobalizing \\
\hline & United Kingdom & 1969 & $39.8 \%$ & $50.8 \%$ & 2008 & $13.9 \%$ & $34.2 \%$ & -0.007 & $(0.000)$ & -0.004 & $(0.000)$ & Deglobalizing \\
\hline & United States & 1969 & $32.7 \%$ & $43.1 \%$ & 2002 & $16.2 \%$ & $31.6 \%$ & -0.005 & $(0.000)$ & -0.003 & $(0.000)$ & Deglobalizing \\
\hline
\end{tabular}




\begin{tabular}{|c|c|c|c|c|c|c|c|c|c|c|c|c|}
\hline \multirow[b]{2}{*}{ Region } & \multirow[b]{2}{*}{ Economy } & \multicolumn{3}{|c|}{ Earliest Observation } & \multicolumn{3}{|c|}{ Latest Observation } & \multicolumn{2}{|c|}{ Lower Bound Slope } & \multicolumn{2}{|c|}{ Upper Bound Slope } & \multirow[b]{2}{*}{ Category } \\
\hline & & Year & $\begin{array}{l}\text { Lower } \\
\text { Bound }\end{array}$ & $\begin{array}{l}\text { Upper } \\
\text { Bound }\end{array}$ & Year & $\begin{array}{l}\text { Lower } \\
\text { Bound }\end{array}$ & $\begin{array}{l}\text { Upper } \\
\text { Bound }\end{array}$ & Coeff. & P-Value & Coeff. & P-Value & \\
\hline \multicolumn{13}{|c|}{ Early Asian Industrializers } \\
\hline & Hong Kong, China & 1978 & $46.0 \%$ & $54.4 \%$ & 2008 & $5.7 \%$ & $26.4 \%$ & -0.015 & $(0.000)$ & -0.010 & $(0.000)$ & Deglobalizing \\
\hline & Japan & 1976 & $38.1 \%$ & $47.5 \%$ & 2008 & $22.6 \%$ & $39.1 \%$ & -0.005 & $(0.000)$ & -0.003 & $(0.000)$ & Deglobalizing \\
\hline & Korea, Rep. of & 1969 & $65.6 \%$ & $68.7 \%$ & 2008 & $24.1 \%$ & $40.1 \%$ & -0.012 & $(0.000)$ & -0.009 & $(0.000)$ & Deglobalizing \\
\hline \multicolumn{13}{|c|}{ Latin America and the Caribbean } \\
\hline & Bolivia & 1976 & $62.4 \%$ & $66.4 \%$ & 2007 & $48.7 \%$ & $56.2 \%$ & -0.004 & $(0.000)$ & -0.003 & $(0.000)$ & Deglobalizing \\
\hline & Brazil & 1970 & $55.8 \%$ & $61.2 \%$ & 2010 & $26.5 \%$ & $37.8 \%$ & -0.006 & $(0.000)$ & -0.005 & $(0.000)$ & Deglobalizing \\
\hline & Chile & 1975 & $41.5 \%$ & $49.1 \%$ & 2008 & $26.0 \%$ & $39.6 \%$ & -0.003 & $(0.000)$ & -0.001 & $(0.004)$ & Deglobalizing \\
\hline & Costa Rica & 1987 & $45.6 \%$ & $52.3 \%$ & 2008 & $24.7 \%$ & $38.5 \%$ & -0.010 & $(0.000)$ & -0.007 & $(0.000)$ & Deglobalizing \\
\hline & Cuba & 1995 & $40.0 \%$ & $46.3 \%$ & 2008 & $30.1 \%$ & $38.2 \%$ & -0.008 & $(0.000)$ & -0.007 & $(0.000)$ & Deglobalizing \\
\hline & El Salvador & 1975 & $58.1 \%$ & $61.8 \%$ & 2007 & $34.9 \%$ & $37.6 \%$ & -0.008 & $(0.000)$ & -0.008 & $(0.000)$ & Deglobalizing \\
\hline & Haiti & 1969 & $80.3 \%$ & $81.8 \%$ & 1990 & $73.1 \%$ & $75.2 \%$ & -0.005 & $(0.000)$ & -0.004 & $(0.000)$ & Deglobalizing \\
\hline & Honduras & 1970 & $74.3 \%$ & $77.3 \%$ & 2007 & $49.7 \%$ & $56.2 \%$ & -0.008 & $(0.000)$ & -0.007 & $(0.000)$ & Deglobalizing \\
\hline & Jamaica & 1992 & $39.2 \%$ & $47.4 \%$ & 2008 & $25.7 \%$ & $37.1 \%$ & -0.008 & $(0.000)$ & -0.007 & $(0.000)$ & Deglobalizing \\
\hline & Mexico & 1960 & $51.0 \%$ & $57.2 \%$ & 2010 & $29.0 \%$ & $39.6 \%$ & -0.005 & $(0.000)$ & -0.004 & $(0.000)$ & Deglobalizing \\
\hline & Netherlands Antilles & 1989 & $10.6 \%$ & $25.2 \%$ & 2008 & $8.2 \%$ & $28.3 \%$ & -0.002 & $(0.000)$ & 0.001 & $(0.139)$ & Ambiguous \\
\hline & Nicaragua & 1990 & $48.8 \%$ & $53.7 \%$ & 2006 & $43.3 \%$ & $50.6 \%$ & -0.003 & $(0.039)$ & -0.002 & $(0.148)$ & Ambiguous \\
\hline & Panama & 1969 & $47.4 \%$ & $53.0 \%$ & 2008 & $22.7 \%$ & $35.0 \%$ & -0.006 & $(0.000)$ & -0.004 & $(0.000)$ & Deglobalizing \\
\hline & Puerto Rico & 1969 & $30.8 \%$ & $37.9 \%$ & 2008 & $12.0 \%$ & $20.7 \%$ & -0.004 & $(0.000)$ & -0.004 & $(0.000)$ & Deglobalizing \\
\hline & Trinidad and Tobago & 1969 & $41.5 \%$ & $47.1 \%$ & 2008 & $16.6 \%$ & $29.3 \%$ & -0.006 & $(0.000)$ & -0.004 & $(0.000)$ & Deglobalizing \\
\hline & Venezuela & 1975 & $36.6 \%$ & $44.9 \%$ & 2008 & $21.3 \%$ & $32.6 \%$ & -0.005 & $(0.000)$ & -0.004 & $(0.000)$ & Deglobalizing \\
\hline \multicolumn{13}{|c|}{ Small Island Nations } \\
\hline & Bahamas & 1973 & $16.1 \%$ & $28.8 \%$ & 1993 & $9.6 \%$ & $22.9 \%$ & -0.002 & $(0.022)$ & -0.002 & $(0.040)$ & Ambiguous \\
\hline & Barbados & 1976 & $25.9 \%$ & $35.0 \%$ & 2004 & $9.1 \%$ & $20.8 \%$ & -0.006 & $(0.000)$ & -0.005 & $(0.000)$ & Deglobalizing \\
\hline & Montserrat & 1975 & $21.6 \%$ & $30.3 \%$ & 1991 & $12.4 \%$ & $22.4 \%$ & -0.003 & $(0.009)$ & -0.003 & $(0.004)$ & Ambiguous \\
\hline
\end{tabular}




\begin{tabular}{|c|c|c|c|c|c|c|c|c|c|c|c|c|}
\hline \multirow[b]{2}{*}{ Region } & \multirow[b]{2}{*}{ Economy } & \multicolumn{3}{|c|}{ Earliest Observation } & \multicolumn{3}{|c|}{ Latest Observation } & \multicolumn{2}{|c|}{ Lower Bound Slope } & \multicolumn{2}{|c|}{ Upper Bound Slope } & \multirow[b]{2}{*}{ Category } \\
\hline & & Year & $\begin{array}{l}\text { Lower } \\
\text { Bound }\end{array}$ & $\begin{array}{l}\text { Upper } \\
\text { Bound }\end{array}$ & Year & $\begin{array}{l}\text { Lower } \\
\text { Bound }\end{array}$ & $\begin{array}{l}\text { Upper } \\
\text { Bound }\end{array}$ & Coeff. & P-Value & Coeff. & P-Value & \\
\hline \multicolumn{13}{|c|}{ East and Southeast Asia } \\
\hline & China, People's Rep. of & 1982 & $87.2 \%$ & $88.6 \%$ & 2010 & $66.4 \%$ & $71.4 \%$ & -0.007 & $(0.002)$ & -0.006 & $(0.003)$ & Deglobalizing \\
\hline & Indonesia & 1976 & $72.7 \%$ & $75.2 \%$ & 2008 & $53.6 \%$ & $59.6 \%$ & -0.005 & $(0.000)$ & -0.004 & $(0.000)$ & Deglobalizing \\
\hline & Malaysia & 1980 & $54.2 \%$ & $58.6 \%$ & 2008 & $32.7 \%$ & $43.8 \%$ & -0.006 & $(0.000)$ & -0.004 & $(0.000)$ & Deglobalizing \\
\hline & Myanmar & 1978 & $75.4 \%$ & $81.8 \%$ & 1998 & $72.4 \%$ & $76.7 \%$ & 0.000 & $(0.493)$ & -0.002 & $(0.000)$ & Ambiguous \\
\hline & Philippines & 1977 & $62.4 \%$ & $67.7 \%$ & 2008 & $44.3 \%$ & $53.2 \%$ & -0.007 & $(0.000)$ & -0.006 & $(0.000)$ & Deglobalizing \\
\hline & Thailand & 1971 & $82.1 \%$ & $83.7 \%$ & 2008 & $56.4 \%$ & $62.1 \%$ & -0.007 & $(0.000)$ & -0.006 & $(0.000)$ & Deglobalizing \\
\hline \multicolumn{13}{|c|}{ Former Communist Bloc } \\
\hline & Azerbaijan & 1991 & $44.1 \%$ & $49.2 \%$ & 2008 & $44.4 \%$ & $52.3 \%$ & 0.002 & $(0.207)$ & 0.004 & $(0.029)$ & Ambiguous \\
\hline & Estonia & 1989 & $48.3 \%$ & $59.5 \%$ & 2008 & $25.9 \%$ & $41.9 \%$ & -0.011 & $(0.000)$ & -0.008 & $(0.000)$ & Deglobalizing \\
\hline & Hungary & 1992 & $27.1 \%$ & $40.0 \%$ & 2008 & $22.7 \%$ & $38.7 \%$ & -0.002 & $(0.000)$ & 0.000 & $(0.407)$ & Ambiguous \\
\hline & Kyrgyz Republic & 1986 & $49.9 \%$ & $56.4 \%$ & 2008 & $42.8 \%$ & $50.3 \%$ & 0.000 & $(0.979)$ & 0.000 & $(0.966)$ & Ambiguous \\
\hline & Moldova & 1981 & $59.7 \%$ & $64.6 \%$ & 2008 & $42.3 \%$ & $50.4 \%$ & -0.004 & $(0.000)$ & -0.003 & $(0.002)$ & Deglobalizing \\
\hline & Mongolia & 1994 & $10.2 \%$ & $16.4 \%$ & 2008 & $9.0 \%$ & $16.2 \%$ & -0.001 & $(0.000)$ & 0.000 & $(0.820)$ & Ambiguous \\
\hline & Poland & 1981 & $59.5 \%$ & $68.1 \%$ & 2008 & $35.9 \%$ & $45.3 \%$ & -0.010 & $(0.000)$ & -0.008 & $(0.000)$ & Deglobalizing \\
\hline & Romania & 1969 & $73.1 \%$ & $76.8 \%$ & 2008 & $50.5 \%$ & $59.7 \%$ & -0.004 & $(0.000)$ & -0.003 & $(0.000)$ & Deglobalizing \\
\hline & Russian Federation & 1990 & $42.4 \%$ & $48.4 \%$ & 2008 & $27.0 \%$ & $40.4 \%$ & -0.008 & $(0.000)$ & -0.004 & $(0.000)$ & Deglobalizing \\
\hline \multicolumn{13}{|c|}{ Middle East and North Africa } \\
\hline & Egypt & 1970 & $66.5 \%$ & $70.3 \%$ & 2008 & $43.2 \%$ & $50.8 \%$ & -0.007 & $(0.000)$ & -0.006 & $(0.000)$ & Deglobalizing \\
\hline & Israel & 1969 & $33.6 \%$ & $43.7 \%$ & 2008 & $17.0 \%$ & $35.9 \%$ & -0.004 & $(0.000)$ & -0.002 & $(0.000)$ & Ambiguous \\
\hline & Syria & 1970 & $62.9 \%$ & $66.9 \%$ & 2007 & $35.5 \%$ & $43.3 \%$ & -0.010 & $(0.000)$ & -0.009 & $(0.000)$ & Deglobalizing \\
\hline \multicolumn{13}{|c|}{ South Aisa } \\
\hline & Bangladesh & 1984 & $67.8 \%$ & $71.3 \%$ & 2005 & $59.2 \%$ & $66.0 \%$ & -0.004 & $(0.211)$ & -0.003 & $(0.299)$ & Ambiguous \\
\hline & India & 1983 & $75.9 \%$ & $78.9 \%$ & 2011 & $62.0 \%$ & $66.5 \%$ & -0.004 & $(0.004)$ & -0.004 & $(0.008)$ & Deglobalizing \\
\hline & Pakistan & 1973 & $70.2 \%$ & $74.3 \%$ & 2008 & $57.8 \%$ & $63.2 \%$ & -0.004 & $(0.000)$ & -0.004 & $(0.000)$ & Deglobalizing \\
\hline \multicolumn{13}{|c|}{ Sub-Saharan Africa } \\
\hline & Botswana & 1985 & $64.4 \%$ & $67.5 \%$ & 2006 & $39.2 \%$ & $48.1 \%$ & -0.014 & $(0.068)$ & -0.011 & $(0.104)$ & Ambiguous \\
\hline
\end{tabular}




\section{Employment in De Facto Tradable Sectors}

As noted previously, trade restrictions have historically rendered many intrinsically tradable sectors nontradable in fact. It follows that trade liberalization could have resulted in rising employment in de facto tradable sectors if the shift of employment out of intrinsically tradable sectors was overwhelmed by growing de facto tradability of some high-employment intrinsically tradable sectors.

Indeed, one imperfect indicator suggests that the de facto tradability of several sectors has trended upward. We have used the National Input-Output tables for 40 countries to calculate the ratio of exports plus imports to gross production for 16 different goods producing industries in each year from 1995 to 2011. This is a standard proxy for de facto tradability, which when measured at the aggregate (economywide) level is utilized to estimate the trade dependence of nations. When we regress the log of this measure on the year it was measured, separately for each country and industry (i.e., 640 country-industry pairs, or sectors), the growth rate is positive and significant at the $10 \%$ level for 427 goods producing sectors. It exceeds 1\% per annum in 267 of them. When estimated for 19 services subsectors for the same countries, this crude measure of tradability registers statistically significant increases in 369 out of 760 country-industry pairs.

Whether this increase in tradability of goods and services implies an increase in the amount of labor implicated in this trade is unknowable. It is therefore not possible to measure the net effect of these contrasting trends in tradability within and between sectors. De facto tradable employment could therefore have increased or decreased in any particular country and historical moment, even as employment shifted out of intrinsically tradable sectors.

This said, our results on intrinsically tradable employment remain interesting for at least three reasons. First, the most significant barriers to trade have already been removed. Thus, the distinction between de facto and intrinsic tradability of sectors might be of more historic than current interest. The difference between them may be small already, and unlikely to change much in future. Second, even if there is still room for de facto tradability to rise within intrinsically tradable sectors, intrinsically tradable employment itself is already so low in advanced economies, that rising de facto tradability is unlikely to result in large absolute increases in the number of jobs producing tradables. Third, if we are headed for a world in which only $15 \%-40 \%$ of employment remains in intrinsically tradable sectors, the share of employment that is in de facto tradable sectors cannot be any higher than this.

These conclusions could change if technological shifts render tradable services that we classified as intrinsically nontradable based on their geographic distribution in the US in the year 2000. Such technological changes are likely to lower the prices of tradables relative to nontradables, and this could shift demand toward tradable products. However, technological change often generates labor redundancy. The net effects of these shifts on the composition of employment is therefore harder to predict than their effects on intersector wage differences (Blinder 2006). For example, while online retailing has exploded in the US during the last decade and a half, and could eventually render eretailing internationally tradable, e-retailing firms themselves hire notoriously few workers, and certainly fewer than traditional retailing (Cowen 2011, 2013). Moreover, many of the jobs in other sectors that are created by online retailing (warehousing and delivery driving) are obviously place based (nontradable) and counted within the transportation and warehousing sector, whose employment in the US has grown since 2000 while employment in the retail sector remained flat (Spence and Hlatshwayo 2011, Figure 6). 


\section{Trade-Linked Employment}

Trade-linked employment includes tradable employment and employment producing intermediate products for sale to tradable sectors. As in section III.B, we are hindered by the fact that there are no available estimates of how much labor in each sector in each country is intrinsically tradable, as well as by the fact that we do not know how much intrinsically-tradable employment is de facto tradable. As before, we therefore proceed by putting bounds on intrinsically trade-linked employment. We continue to assume, for our lower bound estimates, that only goods are tradable, and for our upper bound estimates, we assume that some services are tradable based on US geographic clustering of industries. Details of these calculations are in Appendix 1. Also, as before, we will use these estimates of intrinsically tradable employment, along with the fact that all de facto tradable products are intrinsically tradable, to inform speculation on de facto tradable employment. Given the low level of trade barriers in place by 2011 (the last year for which we can analyze intrinsically trade-linked employment), we will argue that if recent trends in intrinsically trade-linked employment are indicative of ongoing structural trends, de facto tradable employment should follow suit.

Figure 5 displays the upper and lower bounds for the intrinsically trade-linked employment shares for 40 countries in 1995 and 2011. The left-hand side of Figure 5 plots the 2011 upper bound against the 1995 lower bound, seeking unambiguous evidence of a decline in trade-linked employment. This is found for 10 countries. Three of these are large developing countries still moving out of agriculture (India, the People's Republic of China, Indonesia), and five are Eastern European economies whose supply chains have had to adjust to a post-Soviet industrial landscape (Bulgaria, Romania, Latvia, Lithuania, and Poland). Meanwhile, Turkey deindustrialized and Irish workers moved from agriculture into construction and nontradable services.

The right-hand side of Figure 5 plots the 2011 lower bound against the 1995 upper bound, seeking cases in which trade-linked employment increased unambiguously. No cases are uncovered. Intrinsically trade-linked employment therefore fell unambiguously in 10 countries, and its trajectory cannot be discerned in 30 others.

Table 4 lists the bounds of trade-linked employment in 1995 (year 0) and 2011 (year 1). Economies are ordered by the maximum possible level of trade-linked employment in 2011. The table makes clear why trends in trade-linked employment in so many economies are ambiguous. With the exception of the 10 economies with unambiguously declining trade-linked employment shares, the difference between lower and upper bounds lies in the range of $12 \%-33 \%$. This considerable ambiguity, driven by uncertainty over the percentage of services employment that is tradable, intersects with small changes in the upper and lower bound estimates over time, leaving the trends in trade-linked employment over time ambiguous for these economies.

Table 4 also reveals dramatic differences in the degree of trade-linked employment across economies. Large, lower-income economies appear to be much more trade linked than small higherincome economies. As with tradable employment, this reflects the small size of the agricultural sector in richer economies, and the low levels of compensating manufacturing employment. 
Figure 5: No Across-the-Board Evidence that Trade-Linked Employment Increased

...decreased...

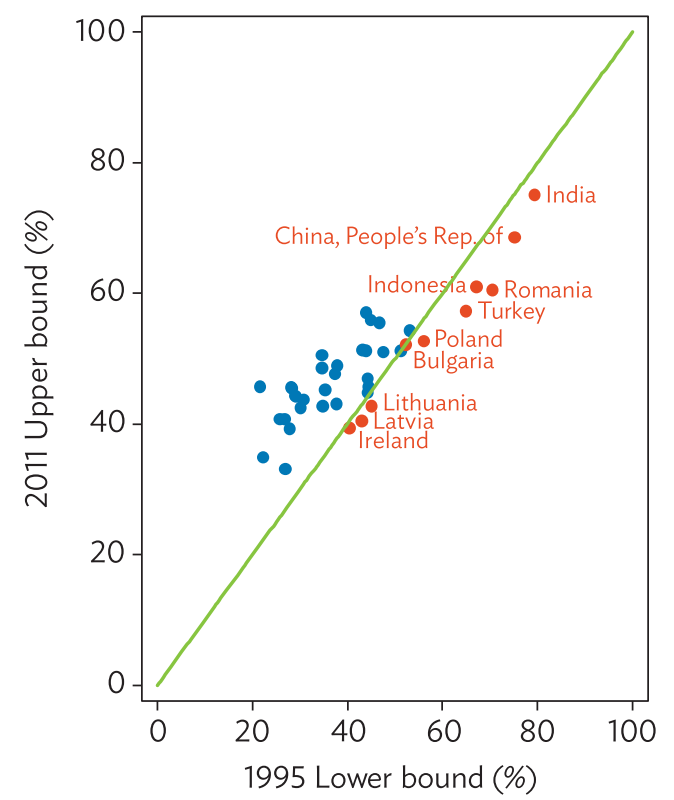

Note: Trade-linked employment decreased unambiguously in countries below the line.

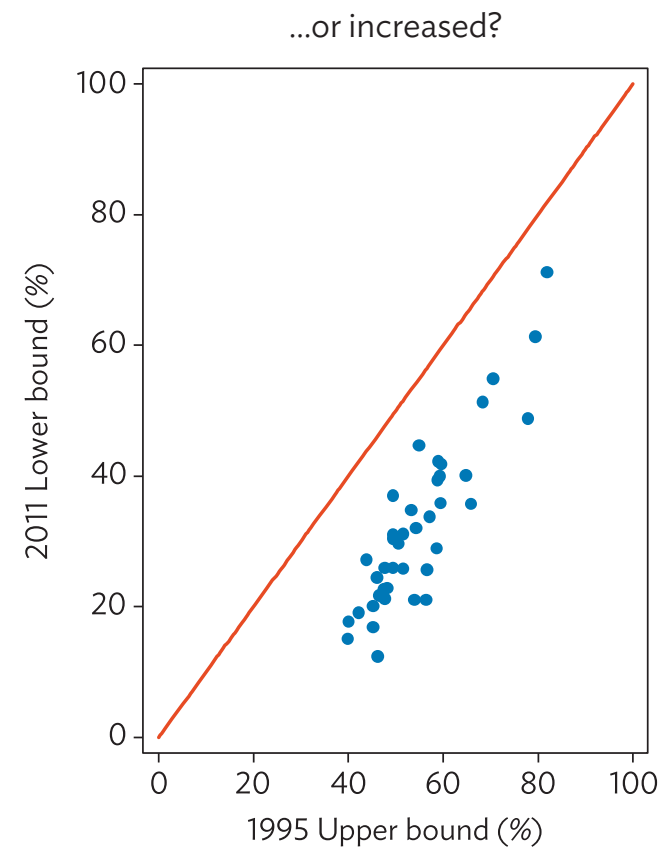

Note: Trade-linked employment increased unambiguously in countries above the line.

Source: Authors' calculations using data from the World Input-Output Database.

One numerical refinement is required before policy conclusions can be drawn. The numbers in Figure 5 shed light on the number of workers whose pay and productivity matter for international competitiveness. We also suggested that this would be the same set of workers whose education and labor protection would matter for competitiveness. The numbers in Figure 5 are probably a reasonable proxy for advanced economies. In many lower income countries, however, vocational training is typically considered for workers in secondary education - which excludes most farmers; and the labor protection that governments are considering trimming do not apply to farmers either. To examine the case for such policy changes, Figure 6 therefore re-estimates trade-linked employment after removing agricultural workers from the numerator and the denominator. In other words, it presents the fraction of nonagricultural employment that is trade linked but not in agriculture. This shifts all countries, save Romania, into the ambiguous category. 
Table 4: Intrinsically Trade-Linked Employments, Upper and Lower Bounds

\begin{tabular}{|c|c|c|c|c|c|c|}
\hline \multirow[b]{2}{*}{ Economy } & \multicolumn{3}{|c|}{1995} & \multicolumn{3}{|c|}{2011} \\
\hline & $\begin{array}{l}\text { Lower } \\
\text { Bound }\end{array}$ & $\begin{array}{l}\text { Upper } \\
\text { Bound }\end{array}$ & Spread & $\begin{array}{l}\text { Lower } \\
\text { Bound }\end{array}$ & $\begin{array}{l}\text { Upper } \\
\text { Bound }\end{array}$ & Spread \\
\hline Cyprus & 26.9 & 40.0 & 13.1 & 17.7 & 33.1 & 15.4 \\
\hline United States & 22.4 & 40.0 & 17.6 & 15.0 & 34.9 & 19.9 \\
\hline Australia & 27.9 & 45.3 & 17.4 & 20.0 & 39.3 & 19.3 \\
\hline Ireland & 40.4 & 53.9 & 13.5 & 21.0 & 39.4 & 18.4 \\
\hline Latvia & 43.0 & 56.4 & 13.4 & 21.1 & 40.4 & 19.3 \\
\hline Malta & 26.8 & 42.3 & 15.5 & 19.1 & 40.7 & 21.6 \\
\hline United Kingdom & 25.9 & 45.2 & 19.3 & 16.9 & 40.7 & 23.8 \\
\hline Denmark & 30.2 & 46.6 & 16.4 & 21.7 & 42.5 & 20.8 \\
\hline Japan & 34.8 & 47.7 & 12.9 & 26.0 & 42.7 & 16.7 \\
\hline Lithuania & 45.2 & 56.6 & 11.4 & 25.7 & 42.8 & 17.1 \\
\hline Greece & 37.7 & 51.7 & 14.0 & 25.8 & 43.1 & 17.3 \\
\hline Sweden & 30.8 & 46.1 & 15.3 & 24.4 & 43.7 & 19.3 \\
\hline France & 29.3 & 47.5 & 18.2 & 22.7 & 44.2 & 21.5 \\
\hline Canada & 29.2 & 43.9 & 14.7 & 27.3 & 44.3 & 17.0 \\
\hline Mexico & 44.3 & 49.6 & 5.3 & 37.1 & 44.8 & 7.7 \\
\hline Spain & 35.3 & 49.5 & 14.2 & 25.9 & 45.2 & 19.3 \\
\hline Belgium & 28.4 & 47.6 & 19.2 & 21.3 & 45.5 & 24.2 \\
\hline The Netherlands & 28.2 & 48.2 & 20.0 & 22.9 & 45.6 & 22.7 \\
\hline Estonia & 44.5 & 58.6 & 14.1 & 28.9 & 45.7 & 16.8 \\
\hline Luxembourg & 21.6 & 46.1 & 24.5 & 12.4 & 45.7 & 33.3 \\
\hline Portugal & 44.4 & 54.2 & 9.8 & 32.0 & 46.9 & 14.9 \\
\hline Finland & 37.5 & 50.7 & 13.2 & 29.6 & 47.6 & 18.0 \\
\hline Austria & 34.7 & 49.4 & 14.7 & 30.4 & 48.6 & 18.2 \\
\hline Italy & 37.9 & 51.6 & 13.7 & 31.2 & 49.0 & 17.8 \\
\hline Germany & 34.7 & 49.4 & 14.7 & 31.0 & 50.5 & 19.5 \\
\hline Brazil & 47.7 & 59.6 & 11.9 & 35.8 & 50.9 & 15.1 \\
\hline Russian Federation & 51.2 & 59.1 & 7.9 & 42.3 & 51.2 & 8.9 \\
\hline Slovak & 44.0 & 57.2 & 13.2 & 33.8 & 51.2 & 17.4 \\
\hline Korea, Rep. of & 43.2 & 53.2 & 10.0 & 34.8 & 51.3 & 16.5 \\
\hline Bulgaria & 52.3 & 59.7 & 7.4 & 41.8 & 52.2 & 10.4 \\
\hline Poland & 56.1 & 64.8 & 8.7 & 40.1 & 52.6 & 12.5 \\
\hline Slovenia & 53.1 & 66.0 & 12.9 & 35.7 & 54.3 & 18.6 \\
\hline Taipei,China & 46.7 & 54.9 & 8.2 & 44.6 & 55.5 & 10.9 \\
\hline Hungary & 45.0 & 59.3 & 14.3 & 40.0 & 55.8 & 15.8 \\
\hline Czech Republic & 44.1 & 58.8 & 14.7 & 39.4 & 57.1 & 17.7 \\
\hline Turkey & 65.1 & 68.3 & 3.2 & 51.3 & 57.3 & 6.0 \\
\hline Romania & 70.5 & 78.0 & 7.5 & 48.8 & 60.5 & 11.7 \\
\hline Indonesia & 67.2 & 70.6 & 3.4 & 54.9 & 61.0 & 6.1 \\
\hline China, People's Rep. of & 75.1 & 79.5 & 4.4 & 61.4 & 68.5 & 7.1 \\
\hline India & 79.4 & 81.9 & 2.5 & 71.1 & 75.1 & 4.0 \\
\hline
\end{tabular}

Source: Authors' calculations using data from the World Input-Output Database. 


\section{Figure 6: No Across-the-Board Evidence that Trade-Linked Employment (Excluding Agriculture) Increased}

...decreased...

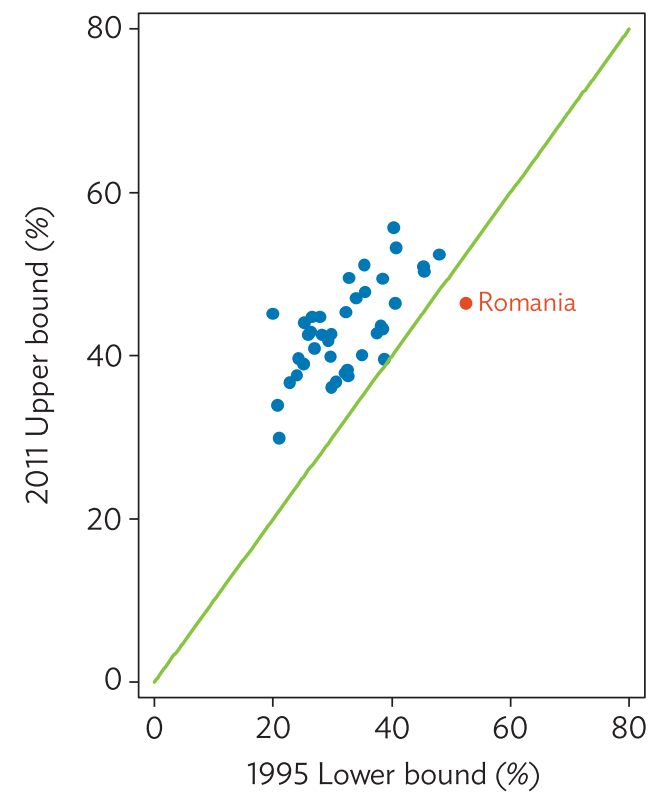

Note: Trade-linked employment (excluding agriculture) decreased unambiguously in countries below the line.

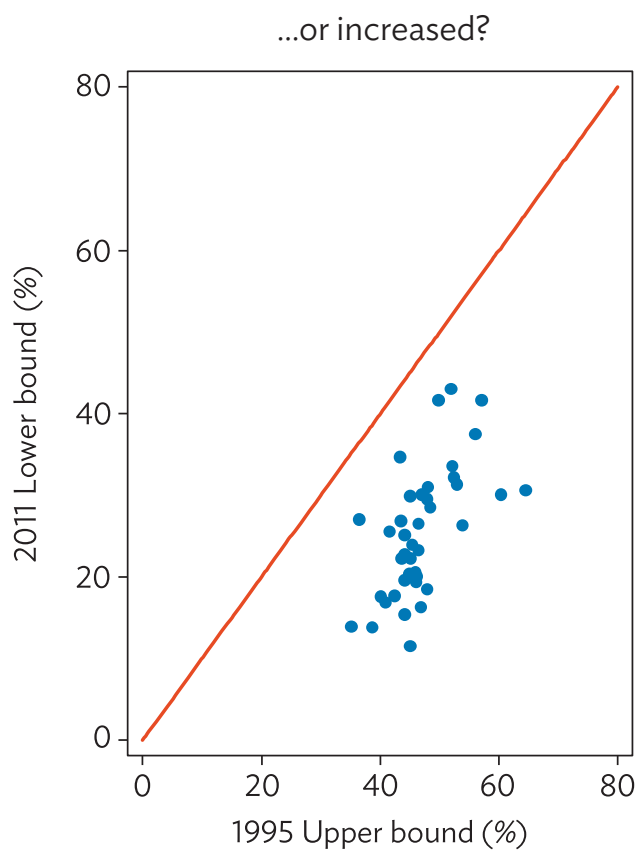

Note: Trade-linked employment (excluding agriculture) increased unambiguously in countries above the line.

Source: Authors' calculations using data from the World Input-Output Database.

\section{A Composite View for Some Large Economies}

So far, we have analyzed tradable employment using ILO and GGDC data, while using WIOD data for export-induced labor demand and trade-linked employment. The time periods analyzed and some definitions vary across these analyses. To obtain a composite view, and thereby make useful structural comparisons between economies, Table 5 presents the levels in each measure using GGDC data in the years 1995 and 2011 for a dozen systemically important economies. Economies are arranged in order of per capita GDP.

Two results that are ensured by construction illustrate propositions from section II: intrinsically trade-linked employment exceeds intrinsically tradable employment at either the upper or lower bound; and, the upper bound estimates of trade-linked employment always exceed the EILD.

We discern a crude clustering of countries in this table.

(i) In the Lowest Income Economies (India, Indonesia, and the PRC) intrinsically tradable and trade-linked employment declined unambiguously as labor moved rapidly out of agriculture and into nontradable, inward-looking services. However, these countries did open up to trade, so that export-induced employment rose modestly, and linkages between nontradable and tradable sectors thickened. Brazil resembles these countries, 
but has more employment in potentially tradable service sectors, as is clear from the larger gap between its upper and lower bounds on tradable and trade-linked employment. Trends in tradable employment in Brazil are therefore ambiguous during this period (though not, we saw in section III.B, over longer time spans).

(ii) Germany; the Republic of Korea; and Taipei,China (to an extent, Japan) are Persistent Manufacturing Economies. They had the highest levels of trade-linked employment among the advanced economies by 2011. They are also the only advanced economies in which the EILD is growing fast. Within this group, Japan has a very low but steadily rising the EILD, which presumably reflects the already high levels of offshored manufacturing production in 1995, and its movement upstream into the management of multinational manufacturing activity in the years since.

(iii) The other advanced economies (United Kingdom, France, and the US) having already transitioned from agriculture and manufacturing into services, have the lowest tradable and trade-linked employment shares in the sample. Changes in the EILD have also been small or negative.

(iv) Mexico, with substantial amounts of export-oriented manufacturing employment near its Northern border and employment trends more typical of a developing economy further south, illustrates the limits of applying a national lens to study this issue.

We therefore conclude that the transition of national economies out of agriculture and into services creates a deglobalizing structural undercurrent, while expanding global trade works in the opposite direction. It is those economies that are most successful in supporting manufacturing that are best able to project labor outward into other countries. In other countries, labor globalization is experienced as a thickening of intersector and international trade flows that displaces some from the tradable sectors, and does not dramatically increase the fraction of the workforce interacting with workers in other countries. 
Table 5: Tradable Employment, Trade-Linked Employment, and Export-Induced Labor Demand for a Common Set of Economics and Years

\begin{tabular}{|c|c|c|c|c|c|c|c|c|c|c|c|c|c|c|}
\hline \multirow[b]{3}{*}{ Economy } & \multirow[b]{3}{*}{$\begin{array}{l}\text { Per Capita GDP } \\
\qquad(2011 \\
\text { International \$) }\end{array}$} & \multicolumn{4}{|c|}{$\begin{array}{c}\text { Share of Employment } \\
\text { in Tradables }\end{array}$} & \multirow[b]{3}{*}{$\begin{array}{c}\text { Conclusion } \\
\text { of Bounds } \\
\text { Analysis }\end{array}$} & \multicolumn{4}{|c|}{ Trade-Linked Employment } & \multirow{3}{*}{$\begin{array}{c}\text { Conclusion } \\
\text { of Bounds } \\
\text { Analysis }\end{array}$} & \multirow{2}{*}{\multicolumn{3}{|c|}{$\begin{array}{l}\text { Export-Induced } \\
\text { Labor Demand }\end{array}$}} \\
\hline & & \multicolumn{2}{|c|}{1995} & \multicolumn{2}{|c|}{2011} & & \multicolumn{2}{|c|}{1995} & \multicolumn{2}{|c|}{2011} & & & & \\
\hline & & $\begin{array}{l}\text { Lower } \\
\text { Bound }\end{array}$ & $\begin{array}{l}\text { Upper } \\
\text { Bound }\end{array}$ & $\begin{array}{l}\text { Lower } \\
\text { Bound }\end{array}$ & $\begin{array}{l}\text { Upper } \\
\text { Bound }\end{array}$ & & $\begin{array}{l}\text { Lower } \\
\text { Bound }\end{array}$ & $\begin{array}{l}\text { Upper } \\
\text { Bound }\end{array}$ & $\begin{array}{l}\text { Lower } \\
\text { Bound }\end{array}$ & $\begin{array}{l}\text { Upper } \\
\text { Bound }\end{array}$ & & 1995 & 2011 & Change \\
\hline India & 4,636 & 73.8 & 76.8 & 63.9 & 68.4 & Fell & 79.4 & 81.9 & 71.1 & 75.1 & Fell & 8.8 & 13.1 & 4.3 \\
\hline Indonesia & 8,838 & 60.8 & 64.1 & 49.2 & 54.6 & Fell & 67.2 & 70.6 & 54.9 & 61.0 & Fell & 13.0 & 14.4 & 1.4 \\
\hline $\begin{array}{l}\text { China, People's } \\
\text { Rep. of }\end{array}$ & 10,384 & 69.4 & 74.1 & 53.9 & 60.7 & Fell & 75.1 & 79.5 & 61.4 & 68.5 & Fell & 16.4 & 18.4 & 2.0 \\
\hline Brazil & 14,973 & 39.3 & 50.8 & 26.4 & 41.3 & Ambiguous & 47.7 & 59.6 & 35.8 & 50.9 & Ambiguous & 8.9 & 12.4 & 3.5 \\
\hline Mexico & 15,923 & 38.8 & 44.3 & 31.2 & 39.5 & Ambiguous & 44.3 & 49.6 & 37.1 & 44.8 & Ambiguous & 15.7 & 16.0 & 0.3 \\
\hline Korea, Rep. of & 31,229 & 35.5 & 45.9 & 25.0 & 41.8 & Ambiguous & 43.2 & 53.2 & 34.8 & 51.3 & Ambiguous & 20.5 & 27.2 & 6.6 \\
\hline Japan & 35,775 & 27.7 & 40.1 & 19.6 & 35.0 & Ambiguous & 34.8 & 47.7 & 26.0 & 42.7 & Ambiguous & 7.8 & 10.8 & 3.0 \\
\hline United Kingdom & 36,456 & 18.3 & 37.4 & 12.0 & 34.0 & Ambiguous & 25.9 & 45.2 & 16.9 & 40.7 & Ambiguous & 17.9 & 19.0 & 1.0 \\
\hline France & 37,457 & 21.2 & 39.4 & 14.0 & 36.2 & Ambiguous & 29.3 & 47.5 & 22.7 & 44.2 & Ambiguous & 18.1 & 17.8 & -0.3 \\
\hline Germany & 42,693 & 25.8 & 41.7 & 19.7 & 41.4 & Ambiguous & 34.7 & 49.4 & 31.0 & 50.5 & Ambiguous & 18.5 & 28.6 & 10.1 \\
\hline United States & 49,791 & 16.4 & 33.8 & 10.8 & 29.4 & Ambiguous & 22.4 & 40.0 & 15.0 & 34.9 & Ambiguous & 8.0 & 7.9 & -0.1 \\
\hline Taipei,China & & 36.5 & 45.2 & 32.6 & 44.5 & Ambiguous & 46.7 & 54.9 & 44.6 & 55.5 & Ambiguous & 31.7 & 39.7 & 8.0 \\
\hline
\end{tabular}

Note: Calculations are explained in Appendix 1

Source: Authors' calculations using data from the World Input-Ouput Database and National Input-Output Table. 


\section{DISCUSSION AND IMPLICATIONS FOR POLICY}

We have examined the idea that national labor markets are becoming more interconnected. We argued at the outset that there are different notions of interconnection, and that each notion has bearing on a different policy debate. Here, we summarize our findings, the areas of ambiguity around them, and lay out what they do and do not mean for different policy debates. What follows are generalizations, with many exceptions detailed in section III.

We were able to produce point estimates of the share of labor demand that is export induced for many economies. This figure has risen in most economies, but not in all of them, and based on within-industry trends alone, not as fast as one might think. This is because while exports have increased rapidly, those industries most involved in exporting have shed workers-presumably because globalization has brought these industries much faster rates of labor productivity growth. Consequently, especially in advanced economies that have deindustrialized in employment, the share of employment that is export induced is now quite low. This may explain why trade and globalization have enjoyed limited electoral support in advanced economies in recent years. More broadly, there is continued divergence across countries in export-induced labor demand: it is both highest and fastest growing in the advanced still-industrial economies (Germany; the Republic of Korea; Taipei,China). This suggests that any incentives to free ride on other economies' stimulus policies are unevenly distributed, and becoming more so.

Next, we showed that the share of employment that is in intrinsically tradable sectors has declined, especially in the lowest-income countries. Declining agricultural employment and weak manufacturing employment growth within countries seems to have more than offset the employment effects of the increasing tradability of services. We could not peg the trend in the share of employment that is de facto tradable. That share has quite possibly increased as trade rules liberalized, despite the structural trends just enumerated. However, as trade restrictions are now quite limited, levels and trends in de facto and intrinsically tradable employment are likely to be more similar in future. Our results therefore suggest that for the foreseeable future, no more than $40 \%$ of any country's labor force will produce goods and services that are internationally tradable. This has implications for exchange rate policy: the number of workers who are hurt by currency undervaluation is likely higher, relative to those that benefit from it, than is commonly suggested.

Finally, to examine the widely circulated idea that education and labor relations policies must be reformed to promote international competitiveness, we attempted to calculate the share of employment that is trade linked. To estimate this figure, we add estimated employment in intrinsically tradable sectors to the estimated amount of labor in other sectors that is directly auxiliary to intrinsic tradables. The upper and lower bounds on intrinsically tradable employment yield upper and lower bounds on trade-linked employment. This analysis is inconclusive with respect to trends in tradelinked employment, indicating that the increasing reliance of nontradable sectors on tradables might be offset by declining employment in intrinsically tradable sectors. Thus, our analysis provides no clear support for (and no evidence against) extending pro-competitive reforms to more workers or sectors to cope with increased trade competition. Moreover, our efforts make clear three sources of ambiguity that make it difficult to evaluate such policy suggestions. First, trends in de facto tradability are not known, so trends in the trade-linked employment share are not knowable. Second, as is common in input-output analysis, the amount of labor demanded from nontradables to serve tradables can only be estimated on the assumption that output per worker in the nontradable sector is the same whether the service is sold to a tradable sector, a nontradable sector or a consumer. And third, the estimates only tell us something about education and labor relations policies if it can be assumed the workers in 
nontradables that sell to tradables are distinct from those that do not. After all, one educates and regulates workers, not tasks, and without assumptions about how completely sectoral work is divided amongst workers, our estimates from input-output analysis can only shed light on the latter. Nonetheless, this clarity about the sources of ambiguity, and the structural trends in intrinsic tradables that we uncover do provide grounds for thinking carefully and perhaps skeptically about claims that globalization requires sweeping reforms to human resource policies. Scalpels may be preferred to brooms. 


\section{APPENDIXES}

\section{Appendix 1: Estimation of Export-Induced and Trade-Linked Labor Demand}

$\mathrm{Z}$ is the matrix recording sales in nominal value terms from 35 producing sectors (in rows) to 35 destination sectors in columns. Final sales of sectors to satisfy final demand from 6 sources (domestic households; the government; nonprofits; firms-for, separately, capital investment and inventory accumulation purposes; and exports to the rest of the world) are recorded in the $35 \times 6$ matrix, F, partitioned according to $\mathrm{F}=\left(\mathrm{f}_{1} \ldots, \mathrm{f}_{5}, \mathrm{x}\right)$, where $\mathrm{x}$ is the $35 \mathrm{x} 1$ vector of exports by sector. Gross sales by sector are recorded in vector y $(35 \times 1) \cdot \hat{y}^{-1}$ is a $35 \times 35$ diagonal matrix in which the reciprocals of the elements of $\mathrm{y}$ form the diagonal. Employment by sector is I $(35 \times 1)$, which is partitioned into our 16 goods and 19 services industries $\mathrm{I}=\left[\mathrm{I}_{\mathrm{G}} \mid \mathrm{I}_{\mathrm{S}}\right]$. Leontief production functions are assumed in each sector, and the utilization of labor and intermediate inputs by each sector is assumed not to depend upon where the output is sold. The following calculations are then standard.

The matrix of Leontief technical coefficients $A=\left[a_{i j} ; i=1 \ldots 35, j=1 \ldots 35\right]$ is recovered by: $\mathrm{A}=\mathrm{Z} \hat{\mathrm{y}}^{-1}$. Gross output is related to intermediate and final demand by: $\mathrm{y}=\mathrm{Zu}_{35}+\mathrm{Fu}_{6} \mathrm{y}$, where $\mathrm{u}_{\mathrm{n}}$ is an $n \times 1$ vector of ones. Putting these expressions together yields $y=(I-A)^{-1}\left(f_{1}+\ldots f_{5}+x\right)$. The $35 \times 1$ vector containing outputs of each sector linked to demand for exports is then $\mathrm{y}_{\mathrm{x}}=(\mathrm{I}-\mathrm{A})^{-1} \mathrm{x}=$ $\left[y_{x, i} ; i=1 \ldots 35\right]$. The amounts of export-linked employment in each sector are $\mathrm{I}_{\mathrm{x}}=$ $\left[l_{i} * y_{x, i} / y_{i} ; i=1 \ldots 35\right]$. Total export linked employment in the economy is $\mathrm{I}_{x}{ }^{\prime} \mathrm{u}_{35}$. The estimated fraction of each sector's gross production that is export linked is $\hat{\mathrm{y}}^{-1} \mathrm{y}_{\mathrm{x}}$. This vector also serves as our estimate of the fraction of each sector's employment that is export linked. For convenience, we label these fractions $\lambda_{1}, . . \lambda_{35}$. The share of all employment economywide that is export linked is given by $\lambda=\left(\mathrm{I}_{\mathrm{x}}{ }^{\prime} \mathrm{u}_{35}\right) /\left(\mathrm{I}^{\prime} \mathrm{u}_{35}\right)$.

Our bounds for intrinsically trade-linked employment are calculated as follows: Define a 35x1 vector capturing the fractions of activities within each of our goods and services sector that are tradable: $\tau=\left[\tau_{\mathrm{G}} \mid \tau\right]$. Both bounds assume goods are intrinsically tradable $\left(\tau_{\mathrm{G}}=\mathrm{u}_{16}\right)$. The lower bound assumes no services are tradable $\left(\tau_{\mathrm{s}}=0\right)$ while the upper bound estimates of services tradability are derived, as before, from the geographic clustering of US industries. In either case, total trade linked employment is calculated as $\mathbf{u}_{35}{ }^{\prime}(\boldsymbol{\tau} \circledast \mathbf{l}+\mathbf{b})$, where $\circledast$ denotes element-wise multiplication of vectors, and each of the 35 elements of $\mathrm{b}$ is given by $b_{i}=\tau_{i} y_{i} \sum_{j=1}^{35}\left(1-\tau_{j}\right) \tau_{j i} / \lambda_{j}$. The $\boldsymbol{\tau} \circledast \mathbf{l}$ term is simply direct employment in tradable sectors. The $\mathrm{b}$ vector is employment in nontradable activities that exists to supply auxiliary services to tradables: $\tau_{i} y_{i}$ is the amount of activity in sector $i$ that is tradable, $a_{j i} / \lambda_{j}$ is the labor demanded in sector $j$ to make possible a unit of activity in sector $i$, and $\left(1-\tau_{j}\right)$ is a correction to ensure that only nontradable employment in sector $j$ gets added to the indirect effects.

\section{Appendix 2: International Labour Organization Data Cleaning Procedures}

We began with the full LABORSTA database, which contains information on the numbers of employed persons over time for 174 countries. In any given country and year, these data can include competing series of estimates from more than one source, and the sources may use different sectoral classifications.

We culled and cleaned this dataset as follows. We first kept observations collected according to the International Standard Industrial Classification (ISIC) revisions 2, 3, or 4, and dropped those 
collected according to ISIC Revision 1. We then dropped series that exclude major sections of the workforce (e.g., rural residents, agricultural workers). In those instances where employment levels in some sectors were missing, but could be inferred from total employment and employment in other sectors (e.g., Spain was missing only agricultural employment in 1978 but provided data on total employment), we filled in the blanks and checked to see whether this yielded discontinuities in the series. Where discontinuities were observed, the series was dropped. Where the information needed to fill in the holes was unavailable (e.g. the series based on Costa Rica's labor force survey has no estimates for mining, utilities or finance between 1976 and 1978 and was dropped) we dropped those years, but not the entire series.

After these adjustments, some countries still had multiple series. For these countries, we combined the series. When two series were available with overlapping years we opted to use the longest available series for those years, and use the data from the remaining years from the shorter series. If two series overlapped temporally and had the same length, we chose the one in ISIC revision 2. If series did not overlap, we spliced them together and checked the total employment series visually for breaks. If the temporal gap between the two series exceeded three years, such a test was not possible. We then checked the resulting total employment series visually to ensure that there were no breaks or anomalies. Once the longer series were assembled, we matched all non-ISIC Revision 2 data and ISIC Revision 2. Finally, we restricted attention to the 67 countries for which the graphically consistent series spanned at least 20 years.

For the People's Republic of China (PRC) we use Census data from 1982, 1990, 1995, 2000, 2005 and 2010. Data from the PRC's Yearbooks are considered less reliable, particularly in their handling of migrant workers (Li and Gibson 2013) and don't cover the rural sector post-2003.

We have produced graphs of the upper and lower bound estimates of intrinsically tradable employment separately for all countries, and found only one country, Botswana, in which these series appear to display sudden jumps.

\section{Appendix 3: Intrinsically Tradable Employment Estimates from Groningen Growth and Development Centre Data}

As noted the ILO data are somewhat limited in their temporal coverage. The GGDC's 10 Sector Database provides longer series on employment shares, typically back to the 1960s, and in some cases to the 1950s. While it only includes data on 42 countries, several of these are not in our ILO dataset, including 11 countries in Sub-Saharan Africa. This Appendix provides details of the country coverage, and graphs are available upon request.

Results using these data reconfirm the impression of a decline in employment in intrinsically tradable sectors. In 39 out of 42 countries, the initial lower-bound is higher than the subsequent upper bound. This includes several countries that fell in the ambiguous category using ILO data: The three exceptions are Singapore, Nigeria and Zambia. In Singapore, the lower bound estimate declines over time and the upper bound estimate increases, leaving it in the ambiguous category. In Nigeria, intrinsically tradable employment declined from over $80 \%$ in 160 to around 50\% in 1982 before climbing back up to over $70 \%$ by 2010 . This $\vee$-shape was driven entirely by a dramatic rebound in Agriculture's share of employment. Zambia is the only country in either dataset in which we see evidence of an increase in intrinsically tradable employment, which rose from around $70 \%$ to around $80 \%$, driven again by agricultural expansion. However, as noted in previous studies (McMillan, Rodrik, and Verduzco-Gallo 2014), the increase in agricultural employment in these two countries is exceptional. 
Appendix 4

Table A4: Assumed Level of Intrinsic Tradability of WIOD and 1-Digit Level ISIC Industries

\begin{tabular}{|c|c|c|c|c|c|c|}
\hline $\begin{array}{l}\text { WIOD } \\
\text { Code }\end{array}$ & Description & $\begin{array}{c}\text { Upper } \\
\text { Bound (EU } \\
\text { Countries) }\end{array}$ & $\begin{array}{l}\text { Upper } \\
\text { Bound } \\
\text { (Non-EU } \\
\text { Countries) }\end{array}$ & How we got this value & 1 Digit & $\begin{array}{l}\text { Upper } \\
\text { Bound } \\
\text { (EU } \\
\text { Countries) }\end{array}$ \\
\hline AtB & Agriculture, Hunting, Forestry and Fishing & $100.00 \%$ & $100.00 \%$ & Goods are tradable & Agriculture & $100.00 \%$ \\
\hline C & Mining and Quarrying & $100.00 \%$ & $100.00 \%$ & Goods are tradable & Mining & $100.00 \%$ \\
\hline $15 \mathrm{t} 16$ & Food, Beverages and Tobacco & $100.00 \%$ & $100.00 \%$ & Goods are tradable & \multirow{14}{*}{ Manufacturing } & \multirow{14}{*}{$100.00 \%$} \\
\hline $17 \mathrm{t} 18$ & Textiles and Textile Products & $100.00 \%$ & $100.00 \%$ & Goods are tradable & & \\
\hline 19 & Leather, Leather and Footwear & $100.00 \%$ & $100.00 \%$ & Goods are tradable & & \\
\hline 20 & Wood and Products of Wood and Cork & $100.00 \%$ & $100.00 \%$ & Goods are tradable & & \\
\hline $21 t 22$ & Pulp, Paper, Printing and Publishing & $100.00 \%$ & $100.00 \%$ & Goods are tradable & & \\
\hline 23 & Coke, Refined Petroleum and Nuclear Fuel & $100.00 \%$ & $100.00 \%$ & Goods are tradable & & \\
\hline 24 & Chemicals and Chemical Products & $100.00 \%$ & $100.00 \%$ & Goods are tradable & & \\
\hline 25 & Rubber and Plastics & $100.00 \%$ & $100.00 \%$ & Goods are tradable & & \\
\hline 26 & Other Non-Metallic Mineral & $100.00 \%$ & $100.00 \%$ & Goods are tradable & & \\
\hline $27 \mathrm{t} 28$ & Basic Metals and Fabricated Metal & $100.00 \%$ & $100.00 \%$ & Goods are tradable & & \\
\hline 29 & Machinery, nec & $100.00 \%$ & $100.00 \%$ & Goods are tradable & & \\
\hline $30 \mathrm{t} 33$ & Electrical and Optical Equipment & $100.00 \%$ & $100.00 \%$ & Goods are tradable & & \\
\hline $34 \mathrm{t} 35$ & Transport Equipment & $100.00 \%$ & $100.00 \%$ & Goods are tradable & & \\
\hline $36 \mathrm{t} 37$ & Manufacturing, nec; Recycling & $100.00 \%$ & $100.00 \%$ & Goods are tradable & & \\
\hline E & Electricity, Gas and Water Supply & $19.15 \%$ & $19.15 \%$ & Jensen et al. (2005), Table 4 & Utilities & $19.15 \%$ \\
\hline $\mathrm{F}$ & Construction & $0.00 \%$ & $0.00 \%$ & $\begin{array}{l}\text { Spence and Hlatshwayo } \\
\text { (2011), Appendix II }\end{array}$ & Construction & $0.00 \%$ \\
\hline 50 & $\begin{array}{l}\text { Sale, Maintenance and Repair of Motor Vehicles } \\
\text { and Motorcycles; Retail Sale of Fuel }\end{array}$ & $0.00 \%$ & $0.00 \%$ & By assumption & & \\
\hline 51 & $\begin{array}{l}\text { Wholesale Trade and Commission Trade, Except of } \\
\text { Motor Vehicles and Motorcycles }\end{array}$ & $0.00 \%$ & $0.00 \%$ & $\begin{array}{l}\text { Spence and Hlatshwayo } \\
\text { (2011), Appendix II }\end{array}$ & Commerce & $7.26 \%$ \\
\hline 52 & $\begin{array}{l}\text { Retail Trade, Except of Motor Vehicles and } \\
\text { Motorcycles; Repair of Household Goods }\end{array}$ & $14.82 \%$ & $14.82 \%$ & $\begin{array}{l}\text { Spence and Hlatshwayo } \\
\text { (2011), Appendix II }\end{array}$ & & \\
\hline
\end{tabular}




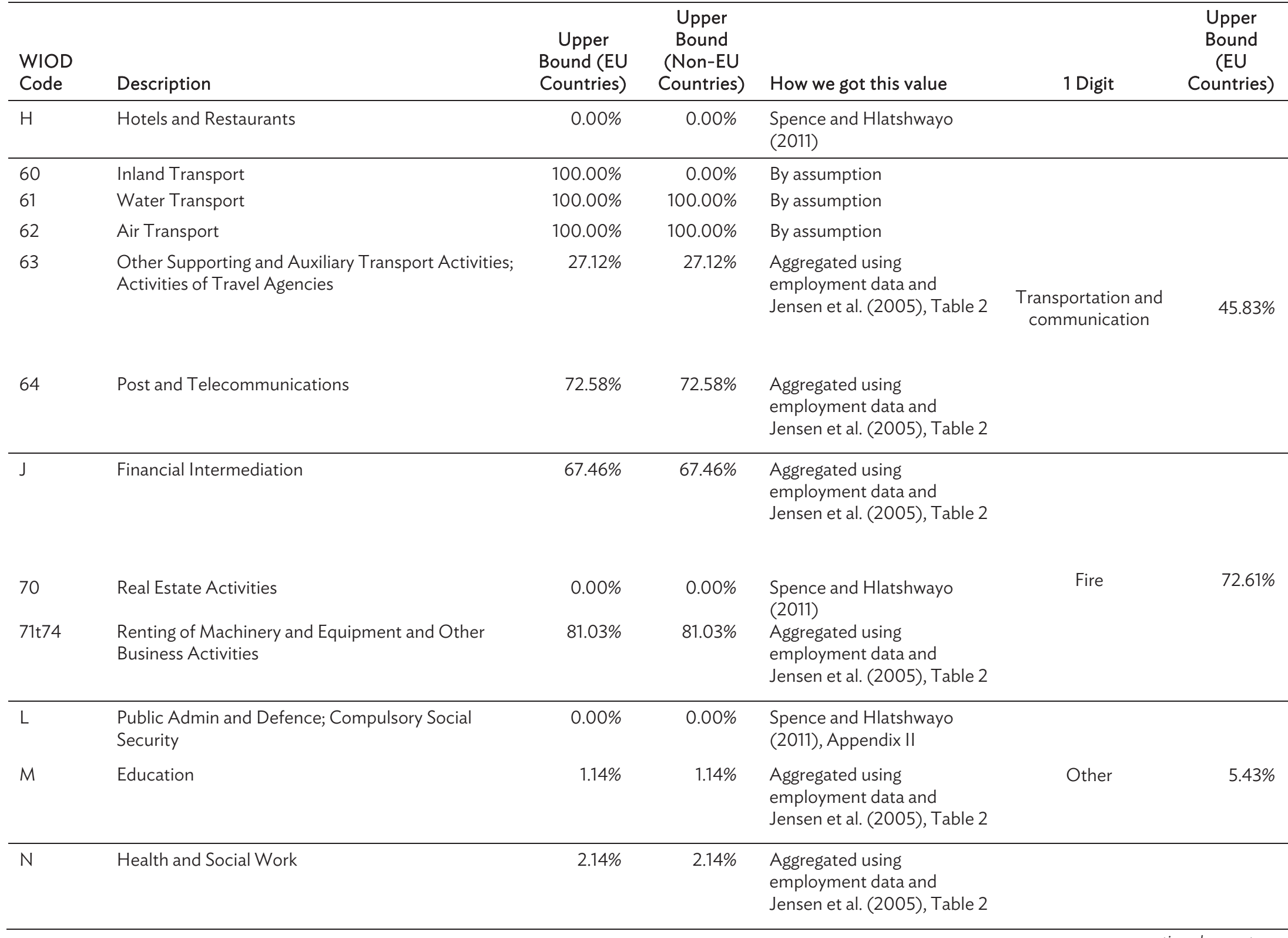




\begin{tabular}{|c|c|c|c|c|c|c|}
\hline $\begin{array}{l}\text { WIOD } \\
\text { Code }\end{array}$ & Description & $\begin{array}{l}\text { Upper } \\
\text { Bound (EU } \\
\text { Countries) }\end{array}$ & $\begin{array}{l}\text { Upper } \\
\text { Bound } \\
\text { (Non-EU } \\
\text { Countries) }\end{array}$ & How we got this value & 1 Digit & $\begin{array}{l}\text { Upper } \\
\text { Bound } \\
\text { (EU } \\
\text { Countries) }\end{array}$ \\
\hline$P$ & Private Households with Employed Persons & $0.00 \%$ & $0.00 \%$ & $\begin{array}{l}\text { Aggregated using } \\
\text { employment data and } \\
\text { Jensen et al. (2005), Table } 2\end{array}$ & & \\
\hline
\end{tabular}

EU = European Union, ISIC = International Standard Industrial Classification, nec = not elsewhere classified, WIOD = World Input-Output Database Source: Authors. 


\section{REFERENCES}

Asian Development Bank (ADB). 2018. Asian Development Outlook 2018: How Technology Affects Jobs. Manila.

Athukorala, Prema-chandra, and Bambang H. Santosa. 1997. "Gains from Indonesian Export Growth: Do Linkages Matter?” Bulletin of Indonesian Economic Studies 33 (2): 73-95.

Baumol, William J., Alan S. Blinder, and Edward N. Wolff. 2003. Downsizing in America: Reality, Causes, and Consequences. New York: Russell Sage Foundation.

Beach, Gary J. 2013. The US Technology Skills Gap: What Every Technology Executive Must Know to Save America's Future. New Jersey: John Wiley \& Sons.

Berger, Suzanne. 2005. How We Compete: What Companies around the World Are Doing to Make It in Today's Global Economy. Crown Business.

Blanchard, Olivier. 2008. "IMF Survey: IMF Spells Out Need for Global Fiscal Stimulus.” IMF News by Camilla Andersen, 29 Dec.

Blinder, Alan S. 2006. “Offshoring: The Next Industrial Revolution.” Foreign Affairs 85 (2): 113.

_. 2009. “How Many US Jobs Might Be Offshorable?” World Economics 10 (2): 41-78.

Blinder, Alan S., and Alan B. Krueger. 2013. "Alternative Measures of Offshorability: A Survey Approach.” Journal of Labor Economics 31 (2): S97-S128.

Brown, Clair, Barry J. Eichengreen, and Michael Reich. 2009. Labor in the Era of Globalization. New York: Cambridge University Press.

Chen, Xikang, Leonard K. Cheng, Kwok-Chiu Fung, Lawrence J. Lau, Yun-Wing Sung, Kunfu Zhu, Cuihong Yang, Jiansuo Pei, and Yuwan Duan. 2012. "Domestic Value Added and Employment Generated by Chinese Exports: A Quantitative Estimation.” China Economic Review 23 (4): 850-64.

Chenoy, Dilip. 2013. "Public-Private Partnership to Meet the Skills Challenges in India." In Skills Development for Inclusive and Sustainable Growth in Developing Asia-Pacific, edited by Rupert Maclean, Shanti Jagannathan, Jouko Sarvi, vol 19, 181-94. Dordrecht: Springer.

Cowen, Tyler. 2011. The Great Stagnation: How America Ate All the Low-Hanging Fruit of Modern History, Got Sick, and Will (Eventually) Feel Better: A Penguin eSpecial from Dutton. Penguin.

2013. Average Is Over: Powering America Beyond the Age of the Great Stagnation. Penguin.

Cwik, Tobias, and Volker Wieland. 2011. "Keynesian Government Spending Multipliers and Spillovers in the Euro Area." Economic Policy 26 (67): 493, 495-549.

Czaika, Mathias, and Hein Haas. 2014. "The Globalization of Migration: Has the World Become More Migratory?” International Migration Review 48 (2): 283-323. 
Dedrick, Jason, Kenneth L. Kraemer, and Greg Linden. 2010. "Who Profits from Innovation in Global Value Chains?: A study of the iPod and Notebook PCs." Industrial and Corporate Change 19 (1): 81-116.

Deyo, Frederic C. 2016. Social Reconstructions of the World Automobile Industry: Competition, Power and Industrial Flexibility. Springer.

Ebenstein, Avraham, Ann Harrison, Margaret McMillan, and Shannon Phillips. 2014. "Estimating the Impact of Trade and Offshoring on American Workers Using the Current Population Surveys." Review of Economics and Statistics 96 (4): 581-95.

Feenstra, Robert C., and Chang Hong. 2010. "China's Exports and Employment." In China's Growing Role in World Trade. University of Chicago Press.

Felipe, Jesus, and Aashish Mehta. 2016. "Deindustrialization? A Global Perspective.” Economics Letters 149: 148-51.

Felipe, Jesus, Aashish Mehta, and Changyong Rhee. 2018. "Manufacturing Matters...but It's the Jobs that Count." Cambridge Journal of Economics: bex086-bex86.

Freeman, Richard B. 2007. "The Challenge of the Growing Globalization of Labor Markets to Economic and Social Policy." In Global Capitalism Unbound. Springer, edited by Eva Paus, 2339. Springer.

Frieden, Jeffry A. 2014. Currency Politics: The Political Economy of Exchange Rate Policy. New Princeton and Oxfordshire: Princeton University Press.

Friedman, Thomas. 2005. The World is Flat: A Brief History of the 21st Century. New York: Picador.

Gereffi, Gary, and Stacey Frederick. 2010. "The Global Apparel Value Chain, Trade and the Crisis: Challenges and Opportunities for Developing Countries." World Bank Policy Research Working Paper 5281.

Harrigan, James, and Rita Balaban. 1999. "US Wages in General Equilibrium: The Effects of Prices, Technology, and Factor Supplies, 1963-1991.” NBER Working Paper No. 6981.

Interview on The Tavis Smiley Show, 25 March 2013. http://www.pbs.org/wnet/tavissmiley/interviews/ lausd-superintendent-dr-john-deasy/.

Jaumotte, Florence, and Irina Tytell. 2008. "How Has the Globalization of Labor Income Affected the Labor Income Share in Advanced Countries?” IMF Working Paper WP/07/298.

Jensen, J. Bradford. 2011. Global Trade in Services: Fear, Facts, and Offshoring. Peterson Institute for International Economics.

Jensen, J. Bradford, Lori G. Kletzer, Jared Bernstein, and Robert C. Feenstra. 2005. "Tradable Services: Understanding the Scope and Impact of Services Offshoring [with Comments and Discussion]." In Brookings Trade Forum, 75-133. Brookings Institution Press. 
Kakaomerlioglu, Dllek Cetindamar, and Bo Carlsson. 1999. "Manufacturing in Decline? A Matter of Definition." Economics of Innovation and New Technology 8 (3): 175-96.

Krugman, Paul R. 1991. Geography and Trade. MIT Press: Cambridge, MA.

Lagarde, Christine. 2016. “Making Globalization Work for All.” In Sylvia Ostry Lecture, edited by C.D. Howe Institute.

Li, Chao, and John Gibson. 2013. "Rising Regional Inequality in China: Fact or Artifact?" World Development 47: 16-29.

Los, Bart, Marcel Peter Timmer, and Gaaitzen Johannes de Vries. 2012. China and the World Economy: A Global Value Chain Perspective on Exports, Incomes and Jobs (Citeseer).

McMillan, Margaret, Dani Rodrik, and Íñigo Verduzco-Gallo. 2014. "Globalization, Structural Change, and Productivity Growth, with an Update on Africa." World Development 63: 11-32.

Modi, Narendra. 2014. Independence Day Speech. https://indianexpress.com/article/india/indiaothers/full-text-prime-minister-narendra-modis-speech-on-68th-independence-day/.

Obstfeld, Maurice, Kenneth S. Rogoff, and Simon Wren-Lewis. 1996. Foundations of International Macroeconomics. Cambridge, MA: MIT Press.

Prasad, Eswar, and Isaac Sorkin. 2009. "Assessing the G-20 Economic Stimulus Plans: A Deeper Look.” In Brookings Institution. http://www.brookings.edu/articles/2009/03_g20_stimulus_prasad. aspx.

Rodrik, Dani. 2016. “Premature Deindustrialization.” Journal of Economic Growth 21 (1): 1-33.

Smith, Adam. 1776. The Wealth of Nations. Cannan Edition. New York: The Modern Library 1937.

Soskice, David W. and Peter A. Hall. 2001. Varieties of Capitalism: The Institutional Foundations of Comparative Advantage. Oxford: Oxford University Press.

Spence, Michael, and Sandile Hlatshwayo. 2011. "The Evolving Structure of the American Economy and the Employment Challenge." In Council on Foreign Relations.

Timmer, Marcel P., Abdul Azeez Erumban, Bart Los, Robert Stehrer, and Gaaitzen J. de Vries. 2014. "Slicing Up Global Value Chains." Journal of Economic Perspectives 28 (2): 99-118.

Tregenna, Fiona. 2010. "How Significant is Intersectoral Outsourcing of Employment in South Africa?" Industrial and Corporate Change 19 (5): 1427-57.

World Economic Forum. 2015. Global Competitiveness Report 2015-2016. Geneva. 


\section{Is Employment Globalizing?}

This paper investigates the claim that national labor markets have become more globally interconnected in recent decades. The authors conclude that the evidence of a large increase in the interconnections between national labor markets is far weaker than commonly asserted. The paper also discusses the implications of these results for different policy debates.

\section{About the Asian Development Bank}

ADB is committed to achieving a prosperous, inclusive, resilient, and sustainable Asia and the Pacific, while sustaining its efforts to eradicate extreme poverty. Established in 1966, it is owned by 67 members48 from the region. Its main instruments for helping its developing member countries are policy dialogue, loans, equity investments, guarantees, grants, and technical assistance. 